\title{
ROYAL FACULTY OF PHYSICIANS AND SURGEONS OF GLASGOW

\author{
GLASGOW LOCK HOSPITAL TRUST PRIZE ESSAY
}

\section{THE LIGHT OF MANY MINDS*}

\author{
BY \\ C. G. A. THOMAS \\ Department of Clinical Pathology, Guy's Hospital, London. \\ Magis erit animorum quam corporum conjugium-ERASMUS
}

\section{INTRODUCTION}

"When $I$ use a word", Humpty Dumpty said in rather a scornful tone, "it means just what I choose it to mean-neither more nor less".--LeWIS CARROLL.

The "basis" of a subject is inevitably a matter of opinion. Although it is unnecessary to go to extremes like Humpty Dumpty and use entirely arbitrary definitions, at the outset it is important to realize that all of us have a more or less personal concept of the meaning and use of words. Thus, while it would be generally agreed that the scientific basis of modern venereology must be considered in relation to the historical development of the subject and in relation to other branches of medical knowledge, the extent to which other aspects are emphasized depends largely on an individual interpretation of the word "basis".

Venereal diseases first became feasible with the evolution of methods of reproduction involving conjugation before cell division. At various times down the ages animals, plants, and various microorganisms became afflicted with diseases which were certainly "conjugal" and which in a wide sense can be called "venereal".

* Submitted to the Royal Faculty of Physicians and Surgeons of Glasgow in April, 1958. The subject prescribed for the essay was "A Survey of the Scientific Basis of the Practice of Venereology (which may include Historical Aspects of the Subject) with Special Reference to the Relationship of Venereology to the Other Branches of Medical Knowledge".
Here, however, we must limit ourselves to diseases transmitted by micro-organisms and furthermore we must consider such diseases as they affect one host, namely Man. The former restriction is necessary to avoid consideration of the unrelated problem of congenitally-transmitted diseases due to genetic aberrations, and the latter is convenient since more is known of these diseases in humans than in other species.

In the present discussion a "venereal disease" implies a disease transmitted by sexual intercourse. Like many definitions this has obvious limitations. Thus syphilis and gonorrhoea are venereal diseases, although in some areas of the world non-venereal spread is common. Conversely, a patient harbouring the protozoon, Trichomonas vaginalis, is not usually regarded as suffering from a venereal disease, but infection by this organism is often transmitted by sexual intercourse.

In common with other sciences, medical knowledge depends ultimately on accurate observations. Initially these observations are confined to naturallyoccurring events, but since these occur at random and are exceedingly complex the observation of artificial, controlled situations is necessary if further progress is to be obtained. The latter approach, that of experimental method, leads to a greater insight into natural phenomena which in turn gives an impetus to further experimental observation.

This interplay is found in all the natural sciences, though its extent at the present day varies in the different branches. In medicine, the experimental 
approach has been relatively slow in starting, and in some fields, such as dermatology, its use has barely begun. In venereology, on the other hand, we have an excellent example of the way this reciprocal relationship develops and of the way the techniques and ideas of other disciplines aid the process.

Anthropologists tell us that compared with the present early Man lived a solitary existence. Whatever the drawbacks of this way of life, he was almost certainly never troubled with any of the major pestilential or infectious diseases which could only come into being when human civilization turned towards communal life. Though conditions were not favourable for the spread of ordinary infectious disease, we have no reason to suppose that venereal disease could not occur. It is clear that some of the causative agents of venereal diseases are amongst the most highly specialized of all human parasites, and it is possible therefore that quite early in his history Man had some form of venereal disease, though not necessarily of the kind found to-day. As a thinking being he presumably observed and considered his symptoms and signs, although he did not realize the fact that he was practising venereology.

\section{EARLY OBSERVATIONS}

\section{The Influence of Pathology}

Venereal disease, in the form of gonorrhoea, has been described since the beginning of recorded time. Although it is notoriously easy to snatch convenient words or phrases from the ancient literature and claim them as evidence that the author understood things which we now believe to be true, we can be quite sure from the Books of Moses that the Jews knew that certain diseases could be spread by contact. Gonorrhoea was one such disease. As with other diseases at this time, it is true that the ultimate cause was attributed to supernatural forces, in particular punishment for arousing the wrath of the Lord, but in addition the immediate cause of gonorrhoea was clearly recognized as sexual intercourse with an unclean person (Leviticus $x v$; Numbers $x x x i)$. The short incubation period of the disease and the site of the first symptoms must have made this conclusion almost inevitable. The cause of gonorrhoea was therefore probably better understood than the cause of any other infectious disease.

However, the concept of transmission of disease by contagion or by infection can have had no general recognition, for no clear reference to such doctrines can be found in later writings of classical Greece and
Rome. For centuries diseases were considered to be of supernatural origin; later this view was gradually replaced by the theory that diseases were caused by natural phenomena such as earthquakes, floods, comets, eclipses, and pollution of the air by "miasmas", and, with the fall of Rome, intellectual hibernation set in and the acquisition of knowledge was at a standstill throughout the Dark Ages.

Interest in the cause and transmission of disease was aroused by the great pandemics of the Middle Ages. Towards the end of this period, at the close of the 15th century, there suddenly appeared in Europe a disease of epidemic proportions which was described by most of the learned physicians of the day as a new disease. Morbus gallicus, its most common appellation, was almost without exception attributed to venereal contact, though some authors such as the Spaniard Juan Almenar made an exception in the case of priests, in whom the disease was believed to be due to the influence of the sun and corruption in the air. Many of the more obvious clinical features of the disease were described in the first 30 years, and there can be no doubt that it was syphilis, differing from the modern disease chiefly in its unusual virulence and severity. However, more important for its ultimate understanding were two remarkable works in which the new disease was not the main object of discussion.

\section{Development of Morbid Anatomy}

In 1505 there appeared a book entitled De abditis nonnullis ac mirandis morborum et sanationum causis. The author, Antonio Benivieni, who had died 3 years earlier, had been a prominent Florentine physician and his book of only 54 pages stands out from the writings of his contemporaries. Instead of sterile commentaries on Galen or Hippocrates and excursions into mysticism, we find an attempt to base diagnosis and prognosis on accurate observation. But the special contribution of Benivieni to scientific medicine was that he took these observations a stage further: as Osler (1921) said, "for the first time in modern literature, we have reports of post mortem examinations made specifically with a view to finding out the exact cause of death". This book was in fact the first textbook of morbid anatomy.

The other outstanding contribution of this period came from Hieronymus Fracastorius. This physician devoted his early years to a wide and practical study of the great epidemics then occurring in Northern Italy, and his later life in contemplating and reflecting on what he had seen. Of his three books on contagion, published in 1546, the first is the most 
important. Fracastorius presents in detail the fundamental concept that contagion is due to the transmission of an agent from one individual to another. However, while he described the seminaria or germs of disease, he could not, as Bulloch (1938) points out, entirely free himself from the views of his predecessors and he had no clear idea that the germs were living agents: to him they were akin to the exhalations of an onion causing lacrimation.

As well as their fundamental contributions to medicine, both Benivieni and Fracastorius had an important influence on the more immediate understanding of the new disease. Thus Benivieni studied a foetus and realized that infection could be transmitted from the mother, and Fracastorius, in his second book on contagion, gave clear and accurate accounts of many aspects of the disease, including transmission to the foetus, a description of gummata, and the observation that manifestations of the disease changed with time. Indeed, looking at the subject from another angle, it is probable that the advent of the new disease was one of the more important stimuli which led to fundamental contributions on infectious disease in general.

How much influence Benivieni and Fracastorius had on their contemporaries is hard to assess, though we know for certain that the works of the latter were widely read in his life-time. In general it seems that much of their work was slowly forgotten. An exception must be made of Fracastorius' famous poem, Syphilis sive morbus gallicus, published in 1530, which tells of the plight of Syphilus, a shepherd smitten with the disease because he "rais'd forbidden altars on the hill" (Tate, 1.686). From this time onwards the new disease was known as "syphilis".

The advances in venereology during the next 300 years were mainly advances in clinical observation. The science of microbiology upon which the modern understanding of venereal disease so largely depends, did not develop sufficiently throughout this long period to be of practical value. On the other hand, in the middle of this period, pathology began to emerge as a science in its own right and exerted an important influence on clinical medicine.

Ambroise Paré (1510-90) described congenital syphilis in great detail; he also suggested syphilis as a cause of aneurysm (Paré, 1840). William Clowes added to the clinical description of syphilis and although he made no really original observations he gave a clear account of the devastating nature of the disease in his day (Clowes, 1579). W. Cockburn wrote a famous book on gonorrhoea in 1713 and located the seat of the disease in the lacunae of the urethra. Like most other physicians of his time he considered that gonorrhoea and syphilis were the same disease (Cockburn, 1719). A very important contribution to venereology was made by the publication in 1738 of De motu cordis et aneurysmatibus by the Italian physiciain, Giovanni Lancisi. Though primarily a text-book of cardiology, this contains the first unequivocal statement of the relationship of syphilis to aneurysm.

Giovanni Battista Morgagni, more than any other person, is recognized as the father of pathology. In his book De sedibus et causis morborum, published in 1761, and translated in 1769 , we have the long awaited development of the ideas propounded earlier by Benivieni in his De abditis. Morgagni was an active physician as well as a brilliant morbid anatomist. In his book both the clinical picture of disease and the post mortem findings are set out in detail and the relationships between the two are discussed. An enormous number of pathological conditions are described including syphilitic aneurysm, aortic incompetence, cerebral gummata, and syphilis of the abdominal viscera (Morgagni, 1769).

Now nosology in the 17th and 18th centuries had largely degenerated into a mere cataloguing of symptoms (the work of Thomas Sydenham, 1624-89, was a notable exception). The essence of Morgagni's contribution was that he rescued medicine from this sterile pursuit of symptoms and directed attention to the individual organs where so often an objective basis of disease could be demonstrated. As Virchow has said, he introduced the "anatomical concept". As pathology developed further it became possible to give rational explanations for many symptoms, and seemingly unrelated symptoms or signs were increasingly recognized as being due to a common pathological process. Interest in the cause and mechanism of disease was stimulated.

\section{Specificity of Venereal Disease}

John Hunter was the first to investigate the specificity of venereal disease, i.e. whether the "venereal poison" was the same in syphilis as in gonorrhoea. In 1767 Hunter inoculated himself with pus from a case of gonorrhoea and, as we now know, the patient must have had syphilis as well, for Hunter developed both a chancre and gonorrhoea. We therefore find in his book "A Treatise on the Venereal Disease", that he maintained, as he implied in the title, that the two diseases were one (Hunter, 1786).

A chancre or "a gonorrhoea" was deemed to be a localized disease and only if this disease persisted was there a danger that morbid poisons might be absorbed to give rise to the dreaded lues venerea. It 
was logical therefore to practice vigorous local treatment, including "destruction of a chancre" by surgery or caustic. As if to underline his error we read that at the post mortem examination on Hunter himself-"The aorta immediately beyond the semilunar valves had its cavity larger than usual, putting on the appearance of an incipient aneurism".

Nevertheless, Hunter made many valuable and accurate clinical observations; for instance, he clearly distinguished the hard chancre from other lesions such as soft chancre. His main contribution was the more general one that simple experimental methods were applicable to medical and surgical problems.

The Edinburgh surgeon, Benjamin Bell, first clearly distinguished the two diseases. In his "Treatise on Gonorrhoea Virulenta and Lues Venerea", he showed on clinical and pathological grounds that gonorrhoea and syphilis were entirely different diseases; further, it was not surprising that the two diseases often coexisted in the same patient (Bell, 1793).

Priority in reaching this conclusion is usually attributed to Philippe Ricord (1799-1889). Ricord was undoubtedly a great authority on venereal disease and in his "Traité pratique des maladies vénériennes" he distinguished syphilis from gonorrhoea (Ricord, 1838). Of particular importance, however, was his unusually colourful and wellknown personality (Oliver Wendell Holmes refers to him as "the Voltaire of pelvic literature"), for his main contribution was that he made his knowledge widely known; the essentials had already been described by Bell.

Unfortunately, Hunter's authority was so great that, in spite of all the evidence to the contrary, confusion continued to exist over the specificity of the two diseases. Indeed, the last vestiges of Hunter's error were not entirely removed until the discovery of the specific microbial causes of the two diseases.

The growing concept of the specificity of disease, i.e. that there are distinct diseases each with its own peculiar properties, was firmly established on the basis of exact clinical and pathological observations by Bretonneau (1778-1862). Studying chiefly diphtheria and typhoid fever, he saw that more than anything else it was the nature of the cause that determined the different clinical and pathological pictures and disease and that diseases should therefore be classified on a causal basis. However, although he referred to the principe contagieux and the agent reproducteur of an infectious disease, he failed to identify these with microbes.

As the ubiquity of microbes became more and more widely recognized, interest in their possible pathological significance increased. Henle (1840) in his "Pathologische Untersuchungen" recognized that the presence of a microbe in a lesion might be puraly accidental and have no causal relation to the disease. On largely theoretical grounds he laid down the unassailable basis for recognizing a pathogenic microbe: it must be constantly present in a lesion; it must be isolated; and the isolated microbe must be tested to see that it can produce the disease. Later, as bacteriology began to emerge as a definite branch of scientific medicine, these same conditions were to be enunciated again by Koch, and are now usually known as "Koch's postulates".

For the time being, however, the specificity of infectious disease was a concept based almost exclusively on clinical and pathological data. It was on such grounds that Hutchinson (1876) realized that, in spite of its occasional eccentricities, syphilis had a biological and clinical history at least as welldefined as that of any of the exanthematous febrile diseases. However, the inability to demonstrate a microbial cause imposed its inevitable limitations: even such a master of the subject as Hutchinson firmly believed that hard chancre and soft chancre were expressions of the same disease.

\section{Development of Cellular Pathology}

Under the influence of Virchow (1821-1902) there were great advances in the study of pathology. His famous periodical, Archiv für pathologische Anatomie und Physiologie und für klinische Medizin, which first appeared in 1847, was dedicated to the study of scientific medicine, but it was his "Cellularpathologie" (1858a) which exerted a really profound influence on medical thought. In effect, Virchow introduced a new way of looking at disease, and from his time onwards the examination of cells in the body fluids and in the tissues (morbid histology) was used to extend and re-define knowledge gained by other means.

A disease such as syphilis could previously be recognized by well-known clinical and post mortem features: now it began to be realized that syphilis had a microscopic individuality as well. Moreover, Virchow confirmed on pathological grounds that syphilis was a disease which involved all the organs and tissues of the body (Virchow, 1858b).

It is sometimes supposed that morbid anatomy as now taught to students began and ended with Virchow. This is not so: the development of his ideas was a slow process and is still continuing. Thus the relation of syphilis to aortitis and aneurysm (discovered and then more or less forgotten several times over the years) was not generally recognized 
until much later (Döhle, 1895; Penrose, 1898). Again, the histopathology of general paralysis of the insane (G.P.I.) was extremely obscure until the work of Nissl (1904), though even he could not be at all certain that syphilis was the cause of this condition.

The influence of pathology on medicine was rarely dramatic but, as Morgagni (1761) remarked in De sedibus, - "Those who have dissected or inspected many bodies, have at least learnt to doubt". The results of this doubting were so successful that pathology soon became an integral part of medicine. In particular the growth of morbid anatomy in the first half of the 19th century drew attention to physical processes in disease and hence to the search for physical signs. Previously, diagnosis of disease had been based largely on the history, attention being paid to physical abnormalities only when these were extremely obvious. But from now on, under the influence of pathology, the importance of physical signs was widely acknowledged.

This change in clinical outlook applied to all diseases, but in a disease such as syphilis, with its manifestations involving so many organs of the body, this search for physical signs was especially successful. Not only were there many superb examples of simple clinical observation-one thinks automatically of Argyll Robertson (1837-1909), Sir Jonathan Hutchinson (1828-1913), and neurologists too numerous to mention-but there was a progressive use of methods which extend our unaided senses: the stethoscope, Laënnec (1781-1826); the ophthalmoscope, von Helmholtz (1821-94); lumbar puncture, Quinke (1842-1922); $X$ rays, Roentgen (1845-1922). All these we now take for granted.

In recent years there have been considerable advances in morbid anatomy and histology while experimental and clinical pathology have developed rapidly. It is very easy to underestimate the importance of pathology. The truth is that the hard-won facts of pathology are so basic that they have become imperceptibly blended into the every-day interpretation of the clinical pictures of disease and their origins are no longer consciously remembered.

\section{THE INFLUENCE OF MICROBIOLOGY}

From its beginnings the science of pathology was important for the understanding of venereal disease. With microbiology the story is quite different. First there was a long period during which microbiology developed in fits and starts without exerting any particular influence on the practice of medicine. Then, suddenly, within a few years, the science expanded dramatically and yielded the richest harvest of useful information ever known to medicine. Venereology was one of the specialties which benefited most. To understand the origins of these dramatic advances we must go back to the 17th century.

Antony van Leeuwenhoek (1632-1723) was undoubtedly the founder of microbiology (Dobell, 1932). With lenses of his own making, he was the first to see an entirely new world, the world of microscopic animalcules. From 1673 onwards, in numerous letters to the Royal Society, he described with pleasure and amazement the antics of his beloved animalcules, which he discovered in such large numbers in water, in infusions of pepper, and in the scum around his own teeth. He carefully estimated their size by comparing them with such things as grains of sand, human red blood corpuscles, "the diameter of the eye of a louse", and "the bigness of a hair on a louse", and we can now deduce that, although many of his animalcules were probably protozoa, others were certainly bacteria. Thus after examining the scum around his teeth he describes with illustrations the three morphological types of micro-organism recognized to-day, namely a coccus, a bacillus, and a " spiral" organism, the last presumably one of the coarse spirochaetes. Although the compound microscope had been invented at the end of the 16th century, the microscopes used by Leeuwenhoek each consisted of a single, accuratelyground, biconvex lens. The most powerful lens amongst those bequeathed by Leeuwenhoek to the Royal Society could magnify about 200 times, and Leeuwenhoek's biographer, Dobell, considers that he must have used some secret method of darkground illumination.

Many of the fundamental landmarks in the subsequent development of microbiology are not of direct medical interest. The observations of Leeuwenhoek were only belatedly confirmed and extended. The most important trend in the next 200 years was that the old ideas of spontaneous generation were progressively undermined by Redi (1626-97), Spallanzani (1729-99), and Schwann (1810-82), and finally disappeared with the work of Pasteur (1822-95) and Tyndall (1820-93); in this process the true nature of fermentation and putrefaction was increasingly understood. The true appreciation of the various morphological types of bacteria was delayed until the work of the botanist Ferdinand Cohn (1828-98).

\section{The Doctrine of Contagium Animatum}

Against this background of a growing awareness of the existence and activity of microbes, speculation 
arose on the significance of microbes in human disease, i.e. the doctrine of contagium animatum. It is true that the idea that certain diseases are caused by animalcules too small for the eye to discern can be traced back as far as the writings of the poets Columella and Varro in the 1st century B.C., but these and many later accounts were poetic rather than scientific.

With the discovery of the microscope intensive studies were made of many of the smaller members of the animal kingdom. In the 17th century several workers independently discovered the Acarus of scabies, which, if not a venereal disease in the usual sense, is certainly acquired under conditions of intimate personal contact.

Only one contemporary of Leeuwenhoek seems to have seen the possible medical significance of the world of animalcules. Benjamin Marten wrote a remarkable but entirely speculative book "A New Theory of Consumptions", first published in 1720. His theory is simple: different infectious diseases can be explained by the activity of "certain species of animalcula or wonderfully minute living creatures"; these microbes by "their spontaneous motion, ill shape or disagreeable parts" are the direct cause of disease in whichever part of the body they ultimately become active; and finally a microbial cause is the best possible explanation for the infectivity of infectious disease.

Thus Marten, realising that "the itch" (scabies) was caused by a "vast number of minute animals", argues that venereal disease is "communicated after the same manner; only as we may conjecture the animalcula abounding in the purulent matter flowing from the small ulcers in that distemper are of a different species, shape and magnitude from those of itch" (Marten, 1722). As often happens to theoretical works ahead of their time, the book had no influence on the science of the day. Indeed, it is so modern in its outlook that, if it were not vouched for by eminent medical historians (including Charles Singer, who re-discovered the book in 1911), one might be forgiven for thinking it a clever 20th century fake.

The doctrine of contagium animatum first became an established fact with the experiments of Agostino Bassi (1773-1856), who studied a silk-worm disease (not the same as pébrine which was the subject of a similar study by Pasteur in 1865-70) which was causing havoc in the Lombardy silk industry. In "Del mal del segno" (1835-6), he showed conclusively that the disease was contagious. Under natural conditions, infection of a healthy worm occurred either by direct contact with a sick worm or indirectly by contact with something such as contaminated food. Bassi showed that it was possible to transmit the disease by means of a pin previously sterilized in a flame. Finally, by microscopic examination, he was able to show that the infective agent was a fungus. He failed to grow the fungus, but showed that it could survive up to 3 years without losing its infectivity. The wider significance of these observations was appreciated by Bassi, who in later writings argued that the theory of contagion by living agents was obviously applicable to various human diseases, including syphilis. Further, he stressed the importance of sterilizing clothing, excreta, and surgical needles by heat or chemicals as a means of preventing the transmission of infectious disease.

\section{Early Microscopic and Experimental Evidence} that Venereal Disease is Caused by Microbes

Alfred Donné (1801-78) was one of the first to investigate the role of living organisms in venereal disease. With gonorrhoea he was unsuccessful in his search for organisms and found only pus cells. With syphilis, however, he discovered a spirochaete in material from chancres, syphilitic ulcers, and cases of balanitis, and he failed to find this spirochaete in non-syphilitic lesions. To investigate the causal role of the organism he carried out experimental inoculations of human subjects with material from syphilitic patients. Unfortunately, the experiments were inconclusive. Donné (1836) also discovered the protozoon, Trichomonas vaginalis, which is now widely recognized as an organism which can be transmitted by sexual intercourse and is sometimes the cause of non-gonococcal urethritis in the male.

Apart from the accidental inoculation of syphilis by John Hunter, the first successful experimental transmission of this disease was described (anonymously) by Bettinger (1856: Hoffmann, 1906, 1912, 1913), and Pellizzari (1862) gave important confirmation that it could be transmitted by inoculation of blood from an infected case. It was, however, Hutchinson who made the inoculability of syphilis widely known, particularly by his dramatic account of the transmission of syphilis by the then common practice of arm to arm vaccination (Hutchinson, 1871). He was quite clear in his own mind that syphilis was caused by a specific organism, but the microscopists of the time were not able to identify it: perhaps it is more accurate to say that they identified a vast number of different organisms as the cause.

In the years 1875 to 1877 , Edwin Klebs, a man of unrivalled experience in microscopic morphology, regularly observed spirochaetes in human syphilitic material; he was also the first to transmit the disease to monkeys (Klebs, E., 1878, 1879; Klebs, A. C., 
1932). The great importance of this work was not generally recognized until much later, largely because the production of obviously syphilitic lesions is fortuitous except in the anthropoid apes. Experimental syphilis was re-born when Metchnikoff and Roux (1903, 1904a, b, 1905) showed that syphilis could be consistently transmitted to chimpanzees.

The spirochaetes seen by Donné probably belonged to one of the species of coarse, non-pathogenic spirochaetes. Klebs, on the other hand, may well have seen the true causative organism; Metchnikoff had no doubt that this was so (Klebs, A. C., 1932). In 1905, Schaudinn, studying material supplied by Hoffmann, demonstrated a delicate, regular, feebly-staining spirochaete, with characteristic movements, in chancres and lymph nodes of patients with syphilis. This organism, now known as Treponema pallidum, was never found in non-syphilitic cases, differing in this respect from the thicker and more irregular spirochaetes which were found in both syphilitic and non-syphilitic lesions (Schaudinn, 1905; Schaudinn and Hoffmann, 1905).

Schaudinn's observations were immediately accepted by the medical profession and over 700 articles on the subject appeared during the next year. All subsequent evidence has supported the view that $T$. pallidum alone is the causative organism of syphilis.

Metchnikoff and Roux (1905) soon confirmed that les spirilles pâles were present in the primary lesions of monkeys with experimental syphilis. Levaditi (1906) drew attention to the value of impregnation with silver nitrate for staining these organisms, and he and other workers later demonstrated the spirochaete in material from congenitally syphilitic infants and in many of the more obvious lesions of adult syphilis. Modern methods of dark-ground illumination came into general use at about this time (Landsteiner and Mucha, 1906).

Perhaps the greatest triumph of this purely morphological approach was the work of Noguchi and Moore (1913). The frequency of syphilis in the history of general paralysis of the insane had been noted long before by Esmarch and Jessen (1857) and, although by 1913 there was a strong feeling that G.P.I. was a manifestation of syphilis, the clinical and pathological picture it presented was unlike that of any other form of syphilis. Using a modified Levaditi silver method, Noguchi and Moore studied seventy cases and demonstrated $T$. pallidum in the brains of twelve undoubted cases of G.P.I.

Meanwhile Neisser (1879) had firmly established the gonococcus as the causal agent of gonorrhoea. He found the characteristic organism (fast immer sieht man zwei Micrococcen dicht aneinander gelagert) in 35 cases of gonorrhoea but failed to find it in pus from chancres or simple vaginal discharges; he also made the important discovery that the gonococcus could be found in ophthalmia neonatorum.

Ducrey (1889) described a minute oval bacillus (now known as Haemophilus ducreyi) invariably present in soft chancres, and Nicolle (1899) produced a typical ulcer in a monkey using pus from a soft chancre. Donovan (1905), in a medical report from Madras, almost casually announced the discovery of specific organisms in the lesions of ulcerating granuloma of the pudenda (granuloma venereum).

\section{The Isolation of Microbes: Microbial Aetiology} of Venereal Disease CONFIRMEd

In the second half of the 19th century microbiology began to advance rapidly in two main directions. In Germany, under the influence of Koch, the emphasis was on technical methods of isolating and studying bacteria: this formed the basis of much of practical bacteriology. In France, under the influence of Pasteur, the chief interest was the attenuation of organisms, the prevention of disease by inoculation, and the processes of recovery. These studies formed much of the basis of immunology.

Koch's outstanding contribution to medical science was that he perfected a simple method of obtaining bacteria in pure culture. The principle of this method was demonstrated in London in 1881, when he showed that by streaking material on gelatin-coated slides it was possible to obtain isolated colonies of bacteria. For several reasons gelatin was not wholly satisfactory and, on the suggestion of Frau Hesse, one of Koch's co-workers, agar (used at this period in the Dutch East Indies for jam-making) was introduced and found to be an almost perfect basis for solid media. For a time Koch used large flat glass plates instead of slides. Finally, Petri became one of the immortals by seeing the advantage of a dish with a lid on it ("Eine kleine Modification ...", Petri, 1887).

From 1881 onwards, and as a direct result of Koch's methods, there was a tremendous surge of activity which rapidly established the aetiology of nearly all human diseases due to specific bacteria. In this era, Ogston $(1881,1882,1883)$ carried out extensive studies on abscesses and concluded that micrococci could cause inflammation and suppuration ("micrococcus poisoning"). In the course of this work he studied material from a few patients with gonorrhoea and soft chancre but unfortunately 
his methods were too primitive to isolate the organisms.

The gonococcus was first grown in pure culture by Bumm (1885), who also demonstrated that urethral inoculation of this organism caused gonorrhoea. The organism seen by Ducrey (1889) in soft chancres was later cultivated by other workers, and typical ulcerative lesions were produced in man and monkeys by inoculation with pure cultures (Tomasczewski, 1903; Reenstierna, 1921; Nicolle, 1923). In recent years small "pleuropneumonialike" organisms (P.P.L.O.) have sometimes been isolated from genital lesions in both sexes but the relationship of these organisms to disease has never been clearly defined (Dienes and Edsall, 1937; Dienes, 1940; Nicol and Edward, 1953; Freundt, 1956).

However, not all organisms can be cultivated by orthodox bacteriological means. Iwanowsky, a Russian botanist, demonstrated that a disease of the tobacco plant known as tobacco mosaic could be transmitted to healthy plants by means of bacteriafree filtrates (Iwanowski, 1892). This was the first scientific demonstration of a virus disease. Loeffler and Frosch (1898) reported that foot-and-mouth disease could also be transmitted by bacteria-free filtrates.

A great deal was already known, particularly from the work of Pasteur, about the behaviour under laboratory conditions of diseases which we now recognize as being due to viruses, but the property. of filterability (in itself of no fundamental importance) was of tremendous practical importance in the early development of all that is now implied by the "isolation" of a virus. Isolation of a virus can be achieved by studying its effect on living cells (as in an experimental animal, in the developing chick embryo, or in tissue culture) or by some other specific in vitro test, but many of the techniques are merely variants of those employed in bacteriology.

Lymphogranuloma inguinale, which first became generally recognized as a venereal disease in 1913 (Durand, Nicolas, and Favre, 1913), was investigated without success by standard bacteriological techniques. In 1929 the virus of this disease was first isolated by Hellerström and Wassén (1931). It was shown that intracerebral inoculation of monkeys with an emulsion of infected glands produced a meningo-encephalitis; the disease could then be passaged to further monkeys, if necessary by means of cell-free filtrates. It was further shown that the central nervous system of monkeys infected in this way contained an antigen with properties similar to the Frei (1925) antigen obtained from infected human pus. To-day the virus can be grown most readily in the yolk sac of the developing chick embryo; it will also grow in certain kinds of tissue culture.

The yolk sac of the developing chick was also used for the first successful cultivation of the causative organism of granuloma venereum (Anderson, 1943; Anderson, DeMonbreun, and Goodpasture, 1945; Anderson, Goodpasture, and DeMonbreun, 1945). The precise nature of this organism is still obscure, but it is clearly not a virus. It appears to have certain similarities to Friedländer's bacillus, but it is very exacting in its requirements for growth and is probably a specific human parasite, since attempts at animal inoculation have been uniformly unsuccessful.

Techniques of modern virology have also been used to study cases of non-gonococcal urethritis. In a few cases it has been possible to isolate and define the causative organism, for instance the virus of inclusion blennorrhoea. In the majority of cases, however, the cause is still obscure, though it is strongly suspected that viruses are responsible.

Syphilis alone remains the important exception, for T. pallidum has not yet been grown in culture, or as Burnet (1953) says "It might be more correct to say that no bacteriologist has ever devised a method by which other bacteriologists could grow these organisms successfully". In spite, therefore, of claims to the contrary-e.g. Noguchi (1911)-the only practical method of maintaining this organism is by serial animal passage, particularly by the intratesticular inoculation of rabbits.

The ability to isolate and study causative organisms enabled the definition and understanding of the venereal diseases to advance rapidly. Thus, in the case of gonorrhoea, a disease in which cultivation of the organism is now accepted as the only reliable diagnostic criterion (McLeod, 1947), it was soon shown conclusively that various manifestations, such as conjunctivitis, arthritis, salpingitis, peritonitis, or even widespread infection throughout the body, could on occasions be part of the same disease: gonorrhoea was clearly more than a localized catarrh. At the same time the gonococcus could sometimes be isolated from women who had no symptoms; this was a considerable advance over the proof used by Hunter, viz. "the only thing we can depend upon is the testimony of those whom we look upon as men of veracity". It was also shown that the gonococcus could be the cause of non-venereal infections such as vaginitis in children; gonococcal conjunctivitis in certain tropical countries could also be non-venereal.

Conversely, it was shown that an organism which looked like a gonococcus was not in fact always a 
gonococcus; furthermore, the inability to isolate the gonococcus from every case of suspected gonorrhoea slowly drew attention to the existence of a large group of patients with non-gonococcal urethritis, sometimes venereal and sometimes not, and due variously to protozoa, pleuropneumonialike organisms, viruses, and frankly unknown causes. The distinction became clearer still when the differential effects of modern treatments became apparent.

Finally, the ability to study the isolated organism in the laboratory was a prerequisite for most of our knowledge about immunity, serological diagnosis, and a rational basis for modern treatments of the disease. There is no doubt that the isolation of causative organisms has been by far the most important step in our understanding of infectious disease.

\section{IMMUNOLOGY}

Value in Diagnosis.-Success in isolating pathogenic bacteria led to rapid advances in immunology. The discovery of tetanus and diphtheria antitoxin by Behring and Kitasato (1890) was an outstanding advance and it seems fitting that their classical scientific paper should end with a quotation from Goethe, Blut ist ein ganz besonderer Saft. This work marks the beginning of an exciting era in which the remarkable properties of this "special kind of juice" were confirmed again and again. The study of immunity in other diseases progressed rapidly and a new subject, serology, was quickly opened up.

Pfeiffer (1894) described the lysis of cholera vibrios in the peritoneal cavity of immunized guinea-pigs and showed that immunity to cholera could be passively transferred. By using serum from an immune animal, lysis could also be demonstrated in vitro, though this effect was abolished if the serum was heated to $60^{\circ} \mathrm{C}$. Fraenkel and Sobernheim (1894) confirmed that such heated serum was inactive in vitro, but showed nevertheless that it was active in vivo. Metchnikoff (1895) showed that, if normal peritoneal fluid was added to a mixture of the bacteria and heated serum, lysis could be demonstrated in vitro. Finally, Bordet (1895) found that normal serum could be substituted for peritoneal fluid, and in classical experiments showed that lysis depended on two distinct factors: complement ("alexine", Bordet) and specific antibody.

Other important antigen-antibody reactions were discovered about this time. Agglutination was described by Durham (1896) and Gruber (1896) working together, and more or less independently by Widal
(1896) and Grünbaum (1897); precipitation was described by Kraus (1897). Neither of these reactions required complement. Meanwhile, Bordet (1898) was largely responsible for showing that lysis of red blood cells could be brought about by similar mechanisms to those causing lysis of bacteria, and Bordet and Gengou (1901) described the complementfixation reaction, fully recognizing its applicability to the study of all antigen-antibody reactions.

$T$. pallidum could not be grown in culture in vitro and no way could be seen of applying the techniques of lysis, agglutination, or precipitation. The gonococcus could be grown, but early serological investigation of this and other cocci gave largely negative or inconclusive results. The complement-fixation reaction was thus the most promising test for studying syphilis and gonorrhoea.

As is well known, Wassermann and his colleagues carried out complement-fixation reactions using as antigen crude watery extracts of the liver of a syphilitic infant. The experiments were dramatically successful. Positive results were obtained with the serum of syphilitic monkeys, the serum of human syphilitic patients, and the cerebrospinal fluid in cases of G.P.I.; negative results were obtained in normal controls (Wassermann, Neisser, and Bruck, 1906; Wassermann, Neisser, Bruck, and Schucht, 1906; Wassermann and Plaut, 1906).

Not so well known is the fact that the use of the complement-fixation test in the diagnosis of syphilis was discovered quite independently by Detre (1906), his article appearing only 2 weeks after the original article of Wassermann, Neisser, and Bruck (1906). Detre's methods differed from those of Wassermann and his colleagues in only minor details, for instance he preferred condylomata as his source of antigen and he used horse erythrocytes.

In the same year the complement-fixation reaction was first successfully applied to the clinical diagnosis of gonorrhoea. Using gonococci as antigen, Müller and Oppenheim (1906) obtained a positive result in a case of gonococcal arthritis; this work was confirmed by Bruck (1906).

Many antigen-antibody tests have subsequently been devised for possible diagnostic use in the other venereal diseases. On the whole these tests have been of limited clinical value, though an exception must be made of the complement-fixation reaction as used for the diagnosis of lymphogranuloma inguinale, which has proved to be very useful.

As well as antigen-antibody reactions carried out in vitro, attention has also been given to the effects in vivo of injected antigens as seen in various "skin tests". Such tests have been studied in all the venereal diseases, but only in lymphogranuloma 
inguinale have the results been of much value. Frei (1925) showed that heated pus from the lesions of lymphogranuloma inguinale gave a delayed hypersensitivity (tuberculin-like) reaction when injected into the skin of patients with this disease. This test was very important in helping bring together the apparently diverse conditions (esthiomène, chronic elephantiasis and ulceration of the vulva, and inflammatory stricture of the rectum) which we now recognize as one disease, lymphogranuloma inguinale (Stannus, 1933). In later years more reliable antigen preparations have been obtained from yolk sac cultures of the organism, but even with modern, highly-specific antigens the skin test for lymphogranuloma inguinale is not as reliable as the corresponding complement-fixation reaction.

Antigen-antibody reactions, supplemented in certain instances by skin tests, are of very great importance in the diagnosis, understanding, and management of venereal diseases. To some extent their value in a particular disease is a chance affair, but they clearly offer invaluable information when it is impossible or impracticable to detect the organisms under the microscope or to grow them in culture. In the case of syphilis, the serological investigation of the disease was so important that for a time serology almost overshadowed the existence of syphilis as a clinical entity. Because of the great clinical importance of the serological tests for syphilis, it is useful to consider them separately.

Serological Tests for Syphilis.-These have been the subject of extensive and detailed investigation. It was soon demonstrated that the rationale of the original Wassermann reaction was erroneous, since extracts of normal liver gave identical results (Marie and Levaditi, 1907); extracts of many other normal tissues were later shown to be suitable.

Since tissue extracts were so successful in the complement-fixation reaction it was reasonable to hope that, if similar extracts could be prepared in a suitable solution or colloidal suspension, then it would be possible to demonstrate precipitation or agglutination. This was achieved by Michaelis (1907), and to-day the most widely used test of this kind is the Kahn test (Kahn, 1922). In essentials, however, the complement-fixation reaction and the precipitation reaction measure the same thing by different methods and are one test.

Numerous modifications have improved the methods of preparing the tissue extracts. Alcoholic extracts were soon shown to give better results than aqueous extracts and the complex lipoidal nature of the antigen was increasingly recognized (Landsteiner, Müller, and Pötzl, 1907; Levaditi and Yamanouchi,
1907; Porges and Meier, 1908). The addition of cholesterol was shown to increase the sensitivity of tests (Browning, 1910; Browning, Cruickshank, and Mackenzie, 1910; Browning and Mackenzie, 1911), and in subsequent years much effort was expended in determining the most suitable lipoidal mixtures for use in the tests. More recently the introduction of a highly-purified phospholipid ("cardiolipin") by Pangborn (1941, 1942, 1945) has diminished the variability inherent in the use of crude extracts (Blumberg, Hartney, and Dimmock, 1950; Price and Wilkinson, 1950, 1952).

There have also been numerous modifications in the techniques of performing both the complementfixation and the precipitation reactions. One can summarize this extensive literature by saying that several of these modifications have increased the ease of performing the tests and a few may have added slightly to the reliability or sensitivity of the tests, but none has resulted in any important advance.

In spite of much work the explanation of the complement-fixation and precipitation reactions remains obscure. The antibody responsible for the reaction is a protein (globulin) like other antibodies (Davis, Moore, Kabat, and Harris, 1945; Henriksen, 1947), but the antigen remains empirical with no obvious relationship to $T$. pallidum. A chance chemical similarity between a spirochaetal antigen and some constituent of mammalian lipid is the simplest explanation in the absence of any good evidence to the contrary. Similar "accidental" similarities are by no means rare: a striking example is the antigenic similarity of various rickettsiae to certain strains of Proteus (Weil and Felix, 1916a, b; Felix, 1942).

Apart from the empirical nature of the "antigen", another unusual feature of the standard serum tests for syphilis is that effective anti-syphilitic treatment causes the tests to revert to negative. In many infectious diseases antibody levels begin to fall when the infective agent has been eliminated, but antibodies usually persist for many years and it is unusual for them to be no longer detectable. Yet in syphilis we confidently expect a course of treatment to cause antibodies to disappear completely, usually within a few months, and in fact it is only in a small percentage of cases that this does not occur. The reason for the disappearance of antibodies is obscure: it is not clear whether this represents a quantitative difference from other diseases or whether there is some fundamental difference in the production of these particular antibodies. It is of interest that the antibodies measured by another test for syphilis (the treponemal immobilization test, 
to be considered shortly) are more normal in their behaviour.

The empirical use of the lipid antigen has been a great clinical success. It is true that positive results are sometimes found in a wide range of diseases other than syphilis; moreover, in certain diseases (such as leprosy, malaria, disseminated lupus erythematosus, infectious mononucleosis, and measles) positive results are very common at some stage of the disease (Moore and Mohr, 1952). It is not surprising, therefore, that much of the extensive literature on the serum tests for syphilis stems from attempts to exclude these so-called "biologic false positive" reactions. But in fact, when one considers the millions of times that the complement-fixation and precipitation reactions have been used, it is clear that the problem cases are comparatively rare and that the standard serum tests for syphilis are amongst the most specific of all serological tests.

Even so, the correct diagnosis of syphilis is so important both medically and socially that attempts to evolve a more specific test are continuing. In particular, it has long been realized that it would be more satisfactory if it were possible to demonstrate some direct action of syphilitic serum on the causative spirochaete.

Early attempts to demonstrate agglutination or lysis were made by several workers, but their techniques were unsatisfactory and their results largely inconclusive. More satisfactory, but too cumbersome for most practical purposes, were various animal protection tests. There were based on the discovery that syphilitic infection produced antibodies which in the presence of complement could inactive spirochaetes so that they were no longer infective or were only weakly infective to rabbits (Eberson, 1921; Turner, 1939; Turner, Kluth, McLeod, and Winsor, 1948).

Nelson and Mayer (1949) described conditions suitable for studying the direct action of antibody on living $T$. pallidum. Unlike many previous workers, they realized that strictly anaerobic conditions were essential if these spirochaetes were to be kept alive in vitro. Spirochaetes were extracted from heavilyinfected rabbit testicular syphilomata and suspended in special medium in an atmosphere of 95 per cent. nitrogen and 5 per cent. carbon dioxide. As long as this was done before significant amounts of antibody had been produced by the rabbit, the spirochaetes remained motile and infectious for several days. On incubation with suitably diluted syphilitic serum in the presence of complement, the spirochaetes became non-motile and lost their ability to infect rabbits. In the absence of complement the serum had no effect.

The loss of motility, in particular, was studied. It was a relatively slow process, requiring many hours of incubation, but could be accurately assessed by direct counts of the percentages of motile and nonmotile organisms. By absorbing the syphilitic sera with standard syphilitic "antigen", it was found that the titres in ordinary serum tests for syphilis were greatly diminished, but that the immobilization titres were unaffected. The titres in the two types of test were also shown to behave independently after heat treatment of the serum. It was therefore clear that the antibody responsible for immobilization was distinct from the Wassermann antibody. The serum of normal persons and patients with other diseases did not cause immobilization unless the patient had recently taken antibiotics: this non-specific immobilization could be distinguished since it occurred in the absence of complement.

Many subsequent observations have confirmed that the treponemal immobilization test is a far more reliable indicator of syphilitic infection than any of the tests employing standard lipoidal antigens. As a means of following the effects of treatment, however, it is no substitute for the older tests. This is because immobilizing antibodies usually persist for long periods of time despite treatment which is adequate as judged by the clinical response and the reversal of the standard serum tests (Magnuson and Thompson, 1949; Nelson and Diesendruck, 1951; Chacko, 1953; Wilkinson, 1954; Olansky, Harris, and Price, 1956). Unfortunately, the treponemal immobilization test requires considerable technical skill and effort if the results are to be trusted. This limits its use to special centres.

In recent years attention has again been directed to agglutination tests. With improved techniques it has been possible to prepare heavy suspensions of $T$. pallidum which show little tendency to agglutinate spontaneously and which can be used in agglutination tests for syphilis (Cain, 1953; McLeod and Magnuson, 1953; Hardy and Nell, 1955). Provisionally, the results of these tests seem to be of the same order of reliability as the results of the treponemal immobilization test; it is however too early to be certain that the tests will have a place in routine serology.

There have been many other recent attempts to establish improved tests for syphilis, including the study of precipitin reactions against extracts of spirochaetes (Saurino and DeLamater, 1952), the serological investigation of spirochaetes which can be cultivated in vitro such as Reiter's treponeme (Kolmer, 1942a, b; Puccinelli, 1951 ; D’Alessandro and Dardanoni, 1953; Wilkinson, 1957), and the possibility of using the "immune adherence phenomenon" which occurs when spirochaetes are mixed 
with normal human red cells in the presence of specific antibodies (Nelson, 1953; Miller, Boak, and Carpenter, 1957). There is no doubt, however, that to-day the most promising line of investigation represents a return to the original idea of Wassermann, that $T$. pallidum itself or some product derived from it should be used in complementfixation tests.

This has been attempted by several workers (Portnoy and Magnuson, 1955, 1956; Meinicke, 1956; Ruge, Knothe, and Otten, 1957), but particular mention must be made of the work of Price and Whelan (1957). From 5- to 10-day testicular lesions in rabbits the spirochaetes were extracted, killed by heat, and broken up by shaking with ground glass; the resulting suspension was then used as antigen for complement-fixation tests. In general, the specificity and sensitivity of the treponemal Wassermann reaction appears to be the same as the treponemal immobilization test; in yaws it is probably more sensitive. The great practical advantage of this new test lies in its simplicity. The antigen is comparatively easy to prepare and it is stable; moreover, with suitable techniques, the antigen derived from a single rabbit is adequate for a large number of tests. It would be a considerable advance if this or some similar antigen became readily available to all routine laboratories.

\section{Immunology in Prevention and Treatment}

In the early days of bacteriology it was widely believed that the use of vaccines and antisera would soon prove to be an efficient means of preventing or treating all infectious diseases. These early hopes have been realised in a few diseases, particularly those acute diseases in which one attack gives the subject a high degree of immunity to a second attack. In other diseases attempts to produce artificial immunity have been extremely disappointing: the venereal diseases come into this category.

The reasons for this are not at all clear. It is possible that the antigens of the organisms causing syphilis or gonorrhoea are abnormally weak in stimulating antibody production, or that the organisms are in some way particularly resistant to those humoral and cellular mechanisms which in an acute disease would rapidly clear the body of infectious agents. It is also possible that the particular sites favoured by the organisms are relatively inaccessible to antibodies.

Whatever the reasons, syphilis is a chronic disease, and many authorities consider it doubtful if spontaneous cure ever occurs. Gonorrhoea is probably self-limiting in the majority of cases, but chronic forms of the disease were quite common before the introduction of modern treatments. Further, if a patient is cured of one attack of either disease, he usually shows no obvious clinical immunity against a second attack.

This is not to say that there is no immunity against venereal diseases, for immunity does not imply conditions incompatible with the life of the parasite. Even the earliest writers observed that it was most unusual for a patient to develop a second chancre during the course of syphilis; throughout the ages such cases have been regarded as "collector's pieces" to be written up and discussed with colleagues. Again, it was soon noticed that, although a congenitally syphilitic infant could infect a healthy nurse, it was never known to infect the mother (who was, of course, infected already). This is the famous half-truth or "law" of Simon de Vallambert (1565) and Abraham Colles (1837).

In more modern times immunity to various venereal diseases has been studied under experimental conditions and, though not marked, some immunity has invariably been demonstrated. For instance, many workers have shown that, in established experimental syphilis, superinfection usually fails to cause a primary chancre. However, even this symptom-immunity is misleading since the new spirochaetes may nevertheless gain access to the tissues (Arnold, Wright, and Levitan, 1950); if the strain used for superinfection differs from the original then there may not even be symptomimmunity. Magnuson and his colleagues have recently carried out an extensive and careful series of experiments on human volunteers in Sing Sing Jail. Of particular interest was the observation that, of 26 men who had been treated previously (and apparently adequately) for late latent syphilis, thirteen showed no clinical or serological response to an injection of living virulent $T$. pallidum (Magnuson, Thomas, Olansky, Kaplan, de Mello, and Cutler, 1956).

As with any other infectious disease, the immunity to syphilis is due to the presence of specific antibodies. The antibodies responsible for treponemal immobilization seem more closely related to immunity than do Wassermann antibodies (Eagle and Fleischman, 1948; Nelson, 1952), but it is not possible to define the basis of immunity at all closely, and on present knowledge it seems unlikely that the practical applications of immunology will ever prove of significant value in the prevention or treatment of syphilis.

In gonorrhoea there is some slight evidence that polyvalent gonococcus vaccine was at one time of 
some value in treatment, but for practical purposes the advent of modern antibiotics has rendered such treatment obsolete. There is no evidence that the use of vaccines will prevent this disease.

Although at present there are no effective immunological methods of preventing or treating lymphogranuloma inguinale, these possibilities have never been thoroughly investigated. In particular, it is possible that in the future the disease will be preventable either by orthodox immunological methods (using an avirulent strain of virus, for example) or by some yet to be discovered application of the "interference phenomenon". Such methods might be of value in areas of the world where the disease is common. However, at present this is highly speculative.

\section{THE TREATMENT OF VENEREAL DISEASE}

\section{The Influence of Chemistry}

Though Moses may have had sound views on the contagious nature of gonorrhoea and the prevention of the disease, his treatment was consistent with the prevailing doctrine of causation and involved the sacrifice of turtle-doves (Leviticus $x v$ ). Through the ages various treatments of a more medical nature were tried, but none seems to have been very successful. The treatment of an important surgical complication of the disease, urethral stricture, was somewhat improved: Antonio Guainierio described the use of wax bougies and metal sounds in the middle of the 15th century and James Syme (17991870 ) introduced the operation of external urethrotomy. Later fresh surgical techniques were invented together with a fearsome armamentarium of bougies, sounds, dilators, and other instruments, but all this never succeeded in disproving the age-old surgical maxim "Once a stricture, always a stricture".

Many of the earliest accounts of syphilis recommended the use of mercury, a drug used since earliest times particularly in the treatment of skin diseases. At first the use of mercury was but one of many treatments but very soon it was widely recognized that it had a special place in the treatment of syphilis. We now know that mercury has extremely weak treponemicidal activity in vivo. Nevertheless, for more than four centuries, this metal occupied the fore-front of antisyphilitic therapy and without doubt exerted marked healing influences on many lesions; but in all this time it is probable that mercury never effected a complete cure in a single case.

Additional treatment in the form of iodides and other iodine compounds was introduced in the first half of the 19th century (Wallace, 1836) and there soon arose a strong clinical impression that they were of value in treatment particularly of late gummatous lesions. Iodides are still sometimes used in syphilis in an attempt to prevent the potentially dangerous exacerbations of the syphilitic process which are liable to occur when late syphilis is treated for the first time (Jarisch, 1895; Herxheimer and Krause, 1902; Heyman, Sheldon, and Evans, 1952).

In the concentrations used iodides have no known effect on spirochaetes, so that presumably they exert some direct effect on the lesions; the nature of this effect is quite obscure. The claim that an excised gumma will dissolve in concentrated solutions of potassium iodide is merely picturesque.

Wagner-Jauregg (1887) made a clinical observation which was to be of great importance in the treatment of one form of syphilis. Working in a psychiatric clinic in Vienna he noted the alleviation of mental symptoms in some patients who had contracted typhoid fever. He made the suggestion that it might be possible to treat psychoses by deliberate infection with febrile diseases, malaria being one of the diseases suggested; 30 years later this became a reality, for in 1917 he inoculated three cases of G.P.I. with the blood of a shell-shocked soldier suffering from malaria, and all three cases showed marked improvement (Wagner von Jauregg, 1918).

All subsequent work has confirmed the remarkable efficacy of this empirical form of treatment of G.P.I. It is now known that $T$. pallidum is unusually sensitive to temperatures only slightly above normal body temperature, and this may be a partial explanation. The gonococcus is similarly heat-sensitive (Carpenter, Boak, Mucci, and Warren, 1933; Warren, Scott, and Carpenter, 1937) and treatment of either disease by various forms of hyperthermia is therefore rational; even with the advent of more modern treatments hyperthermia may still have practical value in a few selected cases of both diseases.

\section{Growth of Biological Chemistry: Chemotherapy}

The importance of chemistry in the development of the biological sciences was slowly recognized towards the end of the 19th century. The application of chemical methods by Pasteur had already resulted in spectacular progress in the study of human and animal diseases. There now appeared another genius, Ehrlich (1854-1915) who was to do so much in furthering the union of chemistry and biology (Marquardt, 1949). 
Very early in his career Ehrlich conceived the idea that there were direct chemical affinities between extraneous active substances and substances composing the cells. This principle was sustained throughout his life and pervades the three great branches of his work, his studies on staining, immunity, and chemotherapy. We can see the idea at its simplest in the work on staining which he carried out as a student. The aniline dyes showed a remarkable specificity in staining different elements of the cell: this, he reasoned, must be due to specific chemical affinities. The extension of this idea was that it should be possible to use dyes or other chemical substances to attack an invading microbe without damaging the tissues. Ideally, Ehrlich thought, this might be accomplished with a single massive dose-the concept of therapia sterilisans magna.

The successful development of chemotherapy for syphilis is closely associated with the chemotherapy of trypanosomiasis. For various reasons attention was first directed to trypanosomiasis: in particular trypanosomes produced an infection of constant behaviour in a convenient host (mice), and there was a suggestion that cure, particularly by arsenic compounds, was a possibility. Ehrlich and Shiga (1904) developed the methods by which many effective chemotherapeutic agents have subsequently been obtained, i.e. they discovered a substance of limited activity and then set about the synthesis and comparative study of related compounds. The result was trypan red, a single injection of which sterilized the blood in experimental trypanosome infection. This was the original example of therapia sterilisans magna.

The organic arsenical, atoxyl, was shown by Thomas (1905) to be more effective than inorganic arsenic in treating experimental trypanosomiasis. This observation immediately attracted the attention of Ehrlich who started intensive investigations on the chemotherapy of trypanosomiasis and syphilis which culminated in the synthesis of arsphenamine (Salvarsan) in 1907. Thus within 3 years the cause of syphilis had been established (Schaudinn, 1905), a practical serological test for the disease had been discovered (Wassermann and others, 1906), and now a vastly improved remedy became available. The efficacy of arsphenamine in animal and human infections was demonstrated in 1909 (Ehrlich and Hata, 1910).

Within 3 years arsphenamine came into wide use. Unfortunately, Ehrlich's enthusiasm for therapia sterilisans magna was shared by others, and not for some years was it observed that many months of continuous treatment are required for cure. Over the years other arsenicals were evolved and improved regimes of treatment were introduced. Ehrlich's great contribution was not the introduction of arsphenamine as such, but rather that, in the decade 1904-14, he established nearly all the fundamental concepts and methods of present-day chemotherapy.

As a result of this stimulus, experimental chemotherapy began to develop rapidly in the hands of chemists, pharmacologists, microbiologists, and pathologists. There were many important advances, particularly in the treatment of protozoal infections, but most important was the discovery by Domagk in 1932 that the azo dye, prontosil, would protect mice from death due to streptococcal septicaemia (Domagk, 1935). He noted that the drug was inactive in vitro. Other workers then made the hypothesis that prontosil was split in vivo to give $p$-amino benzene sulphonamide, and it was quickly demonstrated that this substance was an active chemotherapeutic agent in experimental infections (Tréfouël, Tréfouël, Nitti, and Bovet, 1935; Goissedet, Despois, Gailliot, and Mayer, 1936; Forneau, Tréfouël, Tréfouël, Nitti, and Bovet, 1936). The basic knowledge was now available. A whole range of sulphonamides was quickly synthesized and tested in vitro, in experimental animals, and in humans: the successful treatment of gonorrhoea with sulphonamides was just one of many practical outcomes.

\section{Exploitation of the Chemical feats of Microbes: ANTIBIOTICS}

The successful use of man-made chemicals, such as arsphenamine and the sulphonamides, was shortly to be eclipsed by the even more successful use of the chemical substances made by microbes: this was particularly important because many of the man-made chemicals lacked selective toxicity. Pasteur and Joubert (1877) had noted that a culture of pathogenic anthrax bacilli in urine was killed if it was contaminated by common air-borne organisms. Commenting on this and similar experiments they wrote: "tous ces faits autorisent peut-être les plus grandes espérances au point de vue thérapeutique". Ever since these early days of microbiology the inhibition of the growth of one organism by the growth of another has been frequently observed and the possible application of such antagonisms to the treatment of infectious disease has occurred to many investigators.

Thus a serious attempt was made by Emmerich and Löw (1899) to utilize the bactericidal products of Pseudomonas pyocyanea in the treatment of human infections. The extracts proved too toxic for 
parenteral administration, but were nevertheless used locally with considerable success. More promising was the observation of Fleming (1929) that the products of a certain mould were strongly active against a wide range of common pathogens (including the gonococcus) yet non-toxic to mammalian cells. However, attempts to concentrate the active agent were not successful and, apart from some limited trials of local application in infections, the crucial animal experiments were not performed and the clinical possibilities of penicillin were not pursued.

In 1940 Chain and Florey and their co-workers at Oxford succeeded in obtaining penicillin preparations of high antibacterial activity. It was soon evident that these preparations were highly effective in controlling experimental infections in animals and yet did not give rise to toxic effects (Chain, Florey, Gardner, Heatley, Jennings, Orr-Ewing, and Sanders, 1940); the remarkable clinical potentialities of penicillin were quickly demonstrated. This success with penicillin immediately stimulated a world-wide search for other antibiotics and, of many hundreds subsequently discovered, a few have been shown to have useful therapeutic properties. The successful treatment of venereal disease was but one of many practical outcomes: syphilis, gonorrhoea, lymphogranuloma inguinale, granuloma venereum, and chancroid all proved in varying degrees susceptible to one or more of the antibiotics.

Several antibiotics are now in daily use in the treatment of venereal disease, and in recent years much effort has gone into the study of their mode of action. Of particular interest is the discovery by Park and his colleagues (Park and Strominger, 1957) that penicillin-inhibited bacteria accumulate compounds that are components of the cell wall. These and other investigations (Work, 1957), which have shown that cell walls of bacteria differ chemically from those of animal tissues, suggest that penicillin acts by preventing bacterial cell-wall synthesis: this provides a satisfactory explanation of its selective toxicity. The inhibitory action of chloramphenicol, on the other hand, may depend on the fact that it specifically inhibits protein synthesis (Gale, 1953; Gale and Folkes, 1953a, b). In general, however, it is chastening to remember our gross ignorance about the action of these powerful drugs.

\section{Practical Use of Modern Drugs}

The dosage of the various modern drugs is very much a matter of trial and error, though sometimes applied pharmacology may give guidance on such a problem as whether a given drug is likely to penetrate a particular part of the body. No treatment is completely free from hazard, but since the venereal diseases are serious diseases it is wiser to overtreat than to undertreat.

One particular hazard which is now avoidable is the transmission of serum hepatitis. Though it was known to Bassi (1773-1856) that unsterilized needles could transmit infection, it required the abnormal conditions of the second world war to drive this message home (Bigger, 1943; Salaman, King, Williams, and Nicol, 1944; Sheehan, 1944; Howells and Kerr, 1946). Until this time one must admit with regret that venereologists were the main disseminators of this far from trivial disease. One can only offer the rather feeble excuse that the incubation period of serum hepatitis is unusually long.

One unsettled question is whether more than one drug should be used at a time. If it can be shown that the simultaneous use of two drugs entails no added inconvenience or hazard to the patient yet results in a significantly more rapid cure or lessened tendency to relapse, then the use of two drugs is desirable. There is evidence that synergism in this sense occurs in the treatment of experimental syphilis with penicillin in conjunction with arsenic, bismuth, or mercury preparations as well as with iodides (Eagle, Magnuson, and Fleischman, 1946; Kolmer, 1947, 1948, 1950, 1953). There is also clinical evidence that combined treatment with two or more drugs is of value in the treatment of certain types of human syphilis; the use of artificial infection with malaria in conjunction with other treatments is an example of a similar phenomenon.

Even if the cure rate is only slightly increased, one great theoretical advantage of using more than one drug is that this is likely to prevent the emergence of drug-resistant organisms. The argument runs like this. The most likely origin of drug-resistant organisms is that they arise by spontaneous mutation. If the incidence of mutants resistant to any drug singly is, say, $1: 10^{7}$, then the chances that a mutant will arise simultaneously resistant to two drugs is $1: 10^{14}$; or to three drugs, $1: 10^{21}$. Whereas a total population of $10^{7}$ organisms is usual in disease, it is very unlikely that populations as large as $10^{14}$ or $10^{21}$ organisms are ever reached in any disease; it is therefore very unlikely that there will be an opportunity for the emergence of mutants simultaneously resistant to two or more drugs. This may be a simplification of the true state of affairs; nevertheless experiments in vitro suggest that something like this applies to the treatment of infections. 
The extent of the problem presented by drugresistance varies greatly with different organisms. Experimentally, the spirochaete of syphilis can be made slightly more resistant to various drugs, but drug-resistant syphilis has never been of much significance to the clinician. The gonococcus, on the other hand, rapidly develops drug-resistance in the laboratory and in the individual under treatment: this is particularly true when the sulphonamides are used. The use of two drugs should prevent this and thereby not only improve the treatment of the individual but also ensure that drug-resistant organisms are not disseminated in the community.

\section{Prevention of Venereal Disease by Drugs}

Potions designed to guard against the evils of venereal disease are as old as venereology, but until the 20th century they can rarely have achieved their object. To-day it is possible to prevent venereal disease with quite small doses of modern antibiotics provided these are given before or soon after exposure to infection: the problem now is whether it is wise to do this.

The possible dangers of prophylaxis by means of drugs are well-known and include the sensitization of the patient, the emergence of drug-resistant organisms, and the masking of serious disease. These are all dangers which are likely to be accentuated under conditions of poor medical supervision. Antibiotics in small doses have now been given successfully over long periods in attempts to control many infectious diseases and it is true that the theoretical dangers have rarely been encountered. Nevertheless, it has long been axiomatic that venereal diseases should never be treated until the diagnosis is certain, and although the advent of powerful modern drugs may have blunted this axiom slightly, it still demands the greatest respect. On present evidence the prevention of venereal disease will usually be better served by attention to general medical and social measures than by any reliance on drugs.

Gonococcal ophthalmia neonatorum is a serious disease and until recently it was justifiable to make special efforts at prevention by means of drugs. Credé $(1881 \mathrm{a}, \mathrm{b})$ showed very clearly that a dramatic fall in the incidence of the disease could be achieved by the routine use of a solution of silver nitrate. It is now known that on rare occasions silver nitrate causes severe damage to the eye and it is possible that better results can be achieved by the use of penicillin or other antibiotics. However, the status of this disease is altering rapidly. Treatment with antibiotics is so effective that, provided the infant can be kept under observation, most paediatricians now advise against routine preventive measures for this disease. In primitive communities and in heavily populated areas with a high incidence of gonorrhoea, however, gonococcal ophthalmia neonatorum is still a serious problem and routine prophylaxis is probably desirable.

Less certain, though on the whole justifiable, is routine oral prophylaxis in a reasonably controlled population under conditions in which venereal disease (particularly gonorrhoea) is reaching epidemic proportions. Such conditions have occurred in the armed forces (Eagle, Gude, Beckmann, Mast, Sapero, and Shindledecker, 1949). Some people may find the ethics of this doubtful.

\section{OTHER INFLUENCES}

\section{The Fruitful INTER-RELATIONSHips OF THE Medical SCIENCES}

Pathology, microbiology, and chemistry have certainly played a special role in forging a scientific basis for the practice of venereology, but it would be quite unjustifiable to consider such sciences in isolation. All the basic sciences have, in differing degrees, influenced all the basic medical sciences, which in turn have influenced all the disciplines of medicine and surgery.

For instance, one could not begin to understand the many neurological manifestations of syphilis without some knowledge of the structure and function of the nervous system; this knowledge could not have been won if anatomists and physiologists had not been able to avail themselves of the microscopes, the recording devices, the chemical reagents, and so on of the basic sciences. Nor can the influence of the basic sciences be considered only on a technical level.

From a technical level one might argue that Charles Darwin (or many other famous men in the history of science) had no influence on the practice of venereology. In fact Darwin's studies of evolution were so momentous that, as Huxley (1957) says, "he not only introduced a new dimension into biology but changed the entire structure of human thought. Since Darwin, every field of study, from anatomy to human history, from geology to linguistics, must be viewed sub specie evolutionis, as a process". Nowhere can this evolutionary process be seen more clearly than in the variability of microbes. Much of this is now common knowledge: the probability that syphilis has changed its character over the years is of interest; the knowledge that gonococci may become resistant to sulphonamides in a few hours 
is of immediate practical significance in the treatment of a case.

It would clearly be possible to construct such chains of discovery for all the prominent facets of venereology, but this would serve to emphasize only that the methods and concepts of one science commonly influence those of another. It should not be thought that influence flows only from the basic sciences towards the more applied. It is true that the more lasting and important influences do arise from the more fundamental observations, but a reverse flow is always present. Thus, in the two examples recently quoted, it can be recognized that much information about the physiology of the nervous system has been obtained by clinical observations on syphilis and that the introduction of antibiotics into practical medicine has also been a notable contribution to general biology.

This same mutual influence applies at the clinical level. Venereal diseases were for a long time almost exclusively the province of the surgeon, but under the powerful influence of Hutchinson (1828-1913), a surgeon with the outlook of a physician, they quickly passed into the domain of the physician. Gull (1876) wrote, "For too long a time, I think, syphilis was entirely consigned to the tender mercies of the surgeons". Later still the study of venereal diseases became increasingly recognized as a subject in its own right, but it is obvious that although venereal diseases may now be the special concern of venereologists they are also diseases which require the attention of every clinician.

Syphilis in particular may appear in many forms, and it is not surprising that many of its important clinical manifestations were first described by men who would never consider themselves venereologists. Indeed, the syphilitic aetiology of many of these manifestations was not appreciated at the time; for instance, tabes dorsalis was a well-recognized disease long before Fournier (1882) stressed its syphilitic origin. Later clinical observations, particularly when these have been supported by more precise laboratory observations, provided the necessary information or confirmation on aetiology.

Today the diagnosis of syphilis may first be made on the basis of a collapsing pulse by a cardiologist (Vieussens, 1715; Corrigan, 1832); unsteadiness in the dark, lightning pains, or disorganized joints by a neurologist (Romberg, 1851; Charcot and Bouchard, 1866; Charcot, 1868, 1869); a disordered mental state by a psychiatrist (Esmarch and Jessen, 1857); abnormal pupils by an ophthalmologist (Robertson, $1869 \mathrm{a}, \mathrm{b}$ ); malformed teeth by a surgeon (Hutchinson, 1861) or by a dentist (Moon, 1876); swollen knees by a surgeon (Clutton, 1886); or an obscure change in the properties of the cerebrospinal fluid by a pathologist (Lange, 1912, 1913). It would be a sorry candidate for the M.R.C.P. who could not instantly recognize the symptoms of intermittent haematuria due to cold (Dressler, 1854; Harley, 1865; Dickinson, 1865), suggest a simple confirmatory test (Rosenbach, 1880 ), recognize that syphilis was the cause (Murri, 1885), and explain something of the mechanism of cold haemolysis (Donath and Landsteiner, 1904, 1905).

Workers in these other disciplines of medicine and surgery have brought to the study of venereal disease their special techniques and new ways of looking at a problem. Venereologists in turn have contributed to the study of venereal disease by workers in the other disciplines: a delightfully low threshold of suspicion towards venereal disease and a practical and persistent system of treatment and follow-up have been perhaps their special contribution.

\section{THE APPLICATION OF SCIENTIFIC KNOWLEDGE}

Two common fallacies require correction: the first that clinical observation is by its nature imprecise and unscientific; the second that laboratory results have some mystical property which automatically renders them factual and scientific. Probably these views are rarely expressed quite so bluntly; certainly neither of them is true.

\section{Clinical Science}

All sciences depend to a greater or lesser extent on statistical inference. Pierre Louis (1787-1872) was the first to stress the importance of mathematical accuracy (la méthode numérique) in clinical medicine (Louis, 1825, 1835; Klebs, 1906). The more it is possible to isolate a system and eliminate variable factors which may influence it, the greater is the certainty that a given stimulus will be followed by a specific response. Conversely, the more a system is subject to unknown and uncontrollable variables, the greater will be the hazard in predicting the relation between cause and effect. Clinical medicine belongs to the latter group: in the spectrum of certainty it lies mainly in the direction of uncertainty, though of course, different aspects of the subject will occupy different relative positions. How then does clinical medicine solve two essential problems that confront it, namely to predict cause from effect (diagnosis) and then to predict the response to other stimuli (treatment)? 
Problems of a similar type involving many complex factors are not unknown to physical science, and the study of such stochastic processes has resulted in the development of an entirely new branch of statistical mathematics. Theoretically, at least, it would be feasible to deal with clinical medicine using similar methods, and electronic engineers of the future may well be capable of constructing a calculating machine which, given sufficient data, would be able to diagnose and to predict the results of a given treatment. As an indication of the possibilities, Sneath $(1957 \mathrm{a}, \mathrm{b}) \mathrm{has}$ recently shown the great value of the computer in solving a complex biological problem, the scientific classification of bacteria.

Most members of the medical profession, even if unacquainted with cybernetics (Wiener, 1948), will know that the calculating machine already exists. The human mind can be the most superb computer and the real need is to ensure that during its development it receives the right sort of connexions and transistors and that, being formed, it is fed with the right kind of information. Thus, to say that clinical medicine is largely correlative is not to imply that it is unscientific or that its approach needs to be altered, since the very complexity of the system being studied demands the correlation of diverse data. Paradoxically, the great efficiency of the mind as a computer is mainly responsible for the notion that medicine is more "art" than "science".

Let us now try to rationalize these ideas by following a good clinician as he investigates his patients. If he observes in a number of cases that a particular type of ham-coloured rash is always preceded by a particular type of lesion on the genitalia, and conversely that patients with these particular genital lesions always develop the particular rash, he rightly suspects that the two phenomena are related. He classifies the complex and gives it a name.

Occasionally he sees a patient in whom only one phenomenon develops. This new case does not fit his system of classification and he is not able to predict with confidence the course the disease is likely to take. Normally he will do two things. First he will re-examine the patient and make up his mind whether the genital lesion or rash really is what he thought it to be. Maybe it is not, in which case his system of classification will have already proved itself as an instrument of research in drawing.attention to this difference. Secondly he will try to assess how much reliance he can place on the rash alone or on the genital lesion alone as indicators that the patient is suffering from the specific disease. But since the patient is ill, and treatment cannot be delayed, this further evidence will usually depend on what he or others have observed in similar patients in the past.

Let us suppose that when there was no doubt about the diagnosis a large proportion of the patients subsequently developed one or more of various other phenomena such as a collapsing pulse, dementia, or a peculiar dissociation of pupillary reactions (Robertson, 1869a). If the clinician now finds one of these additional features developing in a patient in whom the diagnosis was in doubt, he rightly considers that the diagnosis is strengthened. The amount by which the diagnosis is strengthened depends on the frequency with which these additional features appear in undoubted cases or fail to appear in cases in which there was never any evidence of the disease.

Thus the clinician may argue that a collapsing pulse occurs in many other diseases and by itself offers only little support; dementia is extremely common, but coming on so remorselessly at this early age is very suspicious. However, except in cases of syphilis, he and his colleagues have never seen a case where "although the retina is quite sensitive, and the pupil contracts during the act of accommodation for near objects, yet an alteration in the amount of light admitted to the eye does not influence the size of the pupil" (Robertson, 1869b). The whole process is attributed to experience, either personal or acquired from others. But basically it is statistical and eminently scientific.

The limitation of the purely clinical approach is that the phenomena observed are not necessarily the most fundamental or constant features of disease. Syphilis usually starts with a chancre, a lesion of very characteristic properties, but quite often the chancre is hardly recognizable as such and occasionally, as in congenital syphilis, no chancre develops. The chancre is thus not a constant feature of the disease; nor is it a specific feature since clinically indistinguishable lesions may occasionally be due to other causes. At the other extreme the Argyll Robertson pupil in the complete form recognized by neurologists may be almost specific evidence for syphilis, but unfortunately it is rare. Sometimes the purely clinical approach leads to serious errors. Thus a urethral discharge due to gonorrhoea very commonly co-exists with syphilis and may appear to be a complication of this disease. Theoretically it is possible to distinguish the two diseases by statistical treatment of clinical data; in fact the distinction by this means alone has never been accomplished.

\section{LABORATORY SCIENCE}

If the clinician makes use of certain laboratory information, he finds that he can greatly increase his 
ability to make successful predictions from similar though not identical phenomena. Thus the presence of $T$. pallidum in a suspected chancre is a surer guide than the appearance of the lesion; the presence of a positive Wassermann reaction is more helpful than the particular form taken by the rash, and, though this information will only be of use to him in a future case, the macroscopic and microscopic pathology of syphilitic aortic incompetence and G.P.I. is more distinctive than the corresponding physical signs. Sometimes the laboratory evidence is the only immediate evidence of disease. Thus, in mass surveys it is often found that the majority of sero-positive cases are asymptomatic (Milgrom, 1948) and, though there are many provisos, the clinician usually finds the positive serology more helpful than the negative clinical findings.

The clinician does not claim these laboratory results as alternatives to clinical skill but rather as valuable accessories: both are observations and should be treated as such. They are not entirely specific nor are they constantly present. They cannot therefore offer an infallible "slot-machine" diagnosis, and in an individual case they may be grossly misleading. For example, in an extra-genital chancre it may be impossible to identify the specific spirochaete with certainty, and the report may depend on the whim of the pathologist; the Wassermann reaction may be strongly positive in a disease such as malaria, yet be negative in an active case of tabes dorsalis, and the pathology of syphilitic lesions is by no means always distinctive. We sanguinely hope that the laboratory will answer our questions with a dogmatic "yes" or "no"; its usual answer is "perhaps".

The clinician accepts the laboratory results as he does his own clinical observations. They are statistical concepts and as such have weight only in so far as they have enabled him or his colleagues to make successful predictions in the past. If the clinician is satisfied that for a patient of particular age, sex, and medical history an Argyll Robertson pupil is the most reliable sign of syphilis, he will be entirely scientific if he acts on this in the face of a negative Wassermann reaction. He will not ignore the negative Wassermann reaction-that would be unscientific-but he will store the information in the statistical apparatus which constitutes his experience.

\section{SPeCIFIC Organisms}

The most fundamental step in diagnosing an infectious disease is to isolate the specific organism; almost as important is to show that the body produces specific antibodies against the organism. It is useful to consider the limitations of these two processes when applied to the recognition of venereal disease.

Syphilitic spirochaetes have not yet been grown in culture in vitro; this is a serious limitation for it makes it difficult to define the organism with precision. The various animal tests available are cumbersome, not very precise, and, in any case, unsuitable for routine use. For practical purposes the organism can only be recognized by its morphology, usually the least satisfactory method of identifying a micro-organism; further, though it has been possible in the past to demonstrate the spirochaete in nearly all supposedly syphilitic lesions, the investigation is normally of value only in genital lesions in the male and in certain skin lesions in both sexes. It is perhaps significant that those with most practical experience with spirochaetes are often the most chary of making a firm diagnosis on morphology alone.

The causative organisms of the other important venereal diseases can be cultivated in any reasonably competent laboratory and tested in vitro; their properties can then be defined with varying degrees of precision. One important generalization is that the organisms from any one named venereal disease do not constitute an entirely homogeneous group. There are considerable variations in cultural, biochemical, serological, and pathogenic properties of organisms considered as belonging to the same species. Most of these variations have not been sufficiently characterized to afford any useful clinical information, though an exception must be made of antibiotic sensitivities which are sometimes of importance in the management of a case.

With all the organisms causing venereal diseases it is difficult to obtain material for bacteriological examination except from particular sites and at particular stages of the disease. In general, the specific organisms can most readily be isolated in the early stages of disease; thereafter diagnosis by this means becomes progressively more difficult. However, even if by some fantastic advance in technique it became possible to tell with complete confidence whenever a patient was harbouring one of the specific organisms causing venereal disease, there is no reason to believe that this would solve the problem of diagnosis.

Experience with other infectious diseases suggests that no such simple solution would be forthcoming. The haemolytic streptococcus is rightly considered to be a cause of sore throat, but at a given time 5 to 15 per cent. of the population of Great Britain carry the organism in the throat without symptoms. A 
patient may develop classical typhus as a youth and then after 30 years of sound health succumb to Brill's disease; the rickettsiae responsible for both diseases are the same and have been dormant all the intervening time (Zinsser, 1934). The virus of herpes simplex once acquired is often a parasite for life; actual attacks of herpes may be very frequent or very rare. It is clear that the presence of the infectious agent is not necessarily synonymous with the presence of disease.

It would certainly be surprising if similar phenomena did not occur in the venereal diseases: subclinical infections, the existence of carriers, periods of parasitic activity and quiescence, variable responses by the host-all these have been considered by various workers, but it must be confessed that we are extremely ignorant about these aspects of the host-parasite relationship. The organisms causing syphilis and gonorrhoea certainly seem to be highly specialized parasites and there is no good evidence that they are capable of a free-living or commensal existence. Consequently, if the specific organisms of one of these venereal diseases are isolated, it is usual to assume that the patient is suffering from that disease.

With other venereal diseases the presence of the specific organism is not always synonymous with the presence of disease: often the only safe conclusion is that the patient is harbouring one of these organisms. An example of this distinction is seen in the behaviour of the virus of inclusion blennorrhoea. Primarily this virus is a harmless inhabitant of the cervical canal of many women, but at other times it can be transmitted by venereal means to cause urethritis in the male.

\section{SPECIFIC ANTIBODIES}

If the organisms themselves cannot be demonstrated the next most valuable step in recognizing an infection is to search for specific antibodies. Theoretically it might be argued that the production of antibodies is a more satisfactory guide to the state of the host-parasite relationship than isolation of an organism, since under most conditions the production of antibodies indicates not only that the body has been exposed to the specific chemical substances which compose organisms but that it has reacted to these substances. In practice there are many limitations.

"Specificity" in the immunological sense is not an absolute term: it implies no more than that the reaction of the serum with the antigen under examination occurs at a higher dilution than with other antigens. It has been found that all organisms are composed of many different antigens which may be shared to varying extents with related organisms and sometimes with seemingly remote biological forms and chemical substances. The antigen which is shared least is by definition the specific antigen, and one of the aims of diagnostic serology is to obtain such antigens in the purest possible state.

For instance, the viral antigen routinely used in the complement-fixation reaction and Frei test for the diagnosis of lymphogranuloma inguinale is a group antigen. A positive reaction usually indicates either psittacosis or lymphogranuloma inguinale: the tests are sometimes weakly positive in the closely related diseases trachoma and inclusion conjunctivitis. A positive result must therefore be interpreted in the light of clinical findings. Now, by treating the viruses of lymphogranuloma inguinale or psittacosis in special ways, it is possible to obtain antigen preparations which usually give positive results only with the specific disease. These more specific antigens are only just beginning to emerge from the research level.

The interpretation of the various serum tests for syphilis can be very difficult. Suppose on clinical grounds we assign a large group of patients to one of three categories: suffering from syphilis in various stages; suffering from diseases other than syphilis; normal controls. (For convenience we exclude all those whose category is clinically uncertain). If we now send all the sera to say ten reputable laboratories where technical errors are unlikely, we can be quite confident that, although there may be agreement about the majority of results, there will be disagreement over the results from many cases. Experiments of this kind have often been performed, either as large-scale surveys or in the more informal exchange of sera between friendly laboratories (League of Nations, 1928; Cumming, Hazen, Sanford, Senear, Simpson, and Vonderlehr, 1935; Parran, Hazen, Mahoney, Sanford, Senear, Simpson, and Vonderlehr, 1937).

Some tests are very sensitive and the results will be positive in cases (early syphilis, for example) when other tests are still negative; these sensitive tests will be much more likely to give positive results with diseases other than syphilis or even with an occasional normal person. Other tests are relatively insensitive and will show a low percentage of positives in sera from syphilitics; at the same time these tests are more specific and there will be fewer positives in other diseases and the results in normal controls may be uniformly negative. It is in fact possible to alter the sensitivity of nearly all the tests by very small modifications in technique. A 
further complication is that different laboratories often express their results in different ways.

Now the clinical yardstick used to assess the reliability of these various tests is inevitably liable to error. It therefore comes about that, although it is reasonable to dismiss as impracticable a few tests which are markedly over-sensitive or undersensitive, there remain a large number of tests which for want of definite evidence must be considered as roughly equivalent. Indeed, much of the serology considered to be most reliable does not owe its reputation to any mysterious scientific superiority but to the forgotten human factor-the test has always been performed in the same way and reported in the same way by the same technician in the same laboratory. In brief, the clinician knows what to expect.

Inevitably, the fact that there is no standard test sometimes leads to confusion. The use of standard antigen, standard methods of setting up the tests, standard sera for calibrating the tests, and standard (preferably unambiguous) methods of recording are all desirable and are being increasingly used by the important reference laboratories. But even with a standardized technique the tests can be very confusing; in particular there is the difficult group of biologic false positive reactions.

Now the treponemal immobilization test or the treponemal Wassermann reaction give greater specificity than the ordinary Wassermann reaction and Kahn test, that is to say, the results seem to be better correlated with the presence of syphilitic spirochaetes as judged by other means. Thus there is now considerable agreement that when a negative treponemal immobilization test is found in suspected latent syphilis, a positive Wassermann reaction should be strongly suspected of being non-specific. Conversely, if a negative Wassermann reaction is found in a patient with symptoms or signs which may be attributable to syphilis, a positive treponemal immobilization test is strong confirmatory evidence of the disease. However, even excluding yaws, pinta, and bejel-which in any case are only distinguishable from syphilis on a very flimsy basis (Hudson, 1958)-no-one who has worked with the treponemal immobilization test has claimed that it is entirely specific for the diagnosis or exclusion of syphilis.

Whatever the specificity of the antibody detected in a patient's serum, it is only evidence that the body has been in contact with the relevant antigen at some period in the past. The usual response to the antigens of an infectious agent is that after a latent period there is a rise in antibodies, the level is then maintained during the course of the illness, and finally there is a gradual fall when the infection is eliminated. This is the usual response but there are many variations: the initial rise in antibodies may vary greatly in rate or extent; the antibody level may be very low when the disease is well established; antibodies may persist at a high level when on other grounds the disease is over. It follows that it is usually unwise to define a particular titre of antibody as definite evidence of infection. To see the biological picture as a whole it is far more satisfactory to study the antibody response as a process in time. Even so the interpretation may be very difficult.

The value of serial blood tests is now firmly established in the management of syphilis. If a positive Wassermann reaction becomes negative under the influence of treatment and subsequently remains negative, it is a valuable confirmation that the treatment has been successful. However, this does not always occur and sero-resistant cases remain the bug-bear of syphilotherapy. Is the persistent antibody really due to the continued presence of the spirochaete? If the spirochaete is still present, is it doing any harm? How can we learn whether a course of treatment is doing any harm to the putative spirochaete? These are questions we are unable to answer.

A similar persistence of antibodies is very common in lymphogranuloma inguinale. Here there is considerable collateral evidence that this is due to the persistence of latent virus: for one thing, relapses after treatment are frequent.

In gonorrhoea it is the failure of antibodies to appear which causes most difficulty. Even before modern treatment was available it was found that, although antibodies were frequently detectable in such conditions as gonococcal arthritis or vesiculitis, they often failed to appear when the gonococcus was undoubtedly causing acute urethritis or vulvovaginitis or even in very chronic localized forms of the disease (Medical Research Committee, 1918; Price, 1933). Perhaps the antigenic stimulus of the gonococcus is only slight in certain sites or perhaps our methods of looking for the antibodies are defective. At all events the gonococcal complementfixation test has been completely abandoned in some centres; this may over-emphasize the limitations.

\section{PAST, PRESENT, AND FUTURE}

So far the outstanding contribution of medical science has been that it has pointed the way to the control of the diseases caused by microbial parasites. The success with different diseases has varied greatly. Diseases have a biological individuality 
and the methods successful against one may be inappropriate against another. At one extreme there are the major pestilential diseases, some of which, malaria for example, could probably be completely eradicated on existing knowledge; at the other extreme there are diseases such as tuberculosis, staphylococcal sepsis, and the venereal diseases, where control has proved much more difficult. The particular difficulties in the control of venereal disease can be considered under four headings:

(1) The source of infection is known to be another human being, but especially in the females of the population at risk, it is often very difficult to recognize the early and most infectious stages of the disease. As Hunter said about gonorrhoea "It may appear very strange that a disease which is so violent and well marked in men should be so obscure in women". Louisa's reply to Boswell in 1763 ("I protest I know nothing of the matter") is still given by more than half the female contacts traced to-day (Boswell, 1763).

(2) The venereal diseases themselves are curable conditions if recognized early; if allowed to run unchecked they may become incurable, usually in the sense that various pathological sequelae become inevitable. However, the infectious quality of the diseases can usually be abolished, and deficiencies in our methods of treatment are relatively unimportant in eliminating the source of infection. In fact the speed, simplicity, and efficiency of modern treatment have actually been blamed for a high incidence of re-infection, but perhaps this only reflects lack of interest on the part of the medical attendant.

(3) The mechanism of transmission of venereal disease is well-defined for, although all the venereal diseases may be transmitted by non-venereal means, this is rare, at any rate in civilized communities. The problem is that, short of an "Orwellian" regime, it is extremely difficult to see how one can exert any form of control on such a normal and personal process as sexual intercourse.

(4) Finally, the susceptibility of a new host to venereal disease is high. Not only is the minimal infective dose probably very small-for instance one or two spirochaetes regularly cause disease when injected intratesticularly in rabbits (Magnuson, Eagle, and Fleischman, 1948) - but in general one attack of venereal disease confers negligible immunity against another attack; nor has it proved possible to provide useful immunity by vaccines or other artificial means.

When one considers these difficulties, perhaps the remarkable thing is that venereal diseases are so well-controlled. Reliable statistics on venereal disease are extremely difficult to obtain and great caution is required in their interpretation. Though the total amount of ill-health caused by venereal disease is almost everywhere on the decline, this is not necessarily accompanied by a decline in the number of fresh cases. Gonorrhoea and nongonococcal urethritis in particular are still poorly controlled in many countries (World Health Organization, 1954; Ministry of Health, 1956; King, 1958). There is no doubt that venereal diseases can still be a serious problem and may flare up from time to time.

It is very easy to look back and see the more glaring mistakes of the past: errors in diagnosis, such as failing to look for the spirochaete of syphilis loitering unobtrusively in a case of gonorrhoea; errors in treatment, such as discontinuing treatment of syphilis too early and then failing to provide adequate follow-up; errors in technique, such as the unnecessary killing of patients with serum hepatitis. These mistakes are now made far less frequently and it is fair to say that venereologists are not the main offenders.

It is much harder to look forward and suggest improvements on existing conditions. Certainly, if the practice of venereology generally was brought up to the standards prevailing in the most efficient centres, there would be great improvements; this would be especially true in medically backward countries where venereal diseases still cause serious ravages.

But it would be short-sighted if in our search for improvements we were to limit ourselves to the narrow confines of what is usually defined as medical science. The key to the prevention of venereal disease may well lie in the wider and more nebulous fields of psychology, education, and morality. The medical profession has a clear duty to assess the information from these sources and when desirable apply it through the administrative channels of preventive and social medicine.

Social measures to combat venereal disease are no modern invention: the Mosaic regulations gave precise instructions for the prevention of gonorrhoea and similar rules were quickly formulated on the arrival of syphilis in Europe. If syphilis was indeed first brought to Scotland in 1496 by the motley crowd of foreign adventurers who followed that sorry knave Perkin Warbeck, one can only admire the adroitness with which the Town Councils of Aberdeen and Edinburgh issued their famous edicts. In April, 1497, it was decreed in Aberdeen, in an attempt to stem "the infirmitey cumm out of 
Franche and strang partis, that all licht weman be chargit and ordanit to decist fra thar vicis and syne of venerie,...". As if not to be outdone, the regulations in Edinburgh (September, 1497) not only required that all cases of the disease should be banished to the Isle of Inchkeith, but for good measure included all those who professed to cure it (Comrie, 1932).

But how far is it desirable to deploy our science to the utmost? Should we insist on wider education of the public on the dangers of venereal disease and risk being landed with a population of neurotics? Should we strive for periodic examination of the whole general public or would this cause more harm in the form of anxiety than the good that might arise from picking up the occasional case? Should we demand stricter control of prostitutes or would this be an intolerable imposition on the freedom of the individual? Should we experiment with widespread antibiotic prophylaxis or would this be incredibly dangerous?

Whatever we may feel about these wider aspects of prevention, we must ask ourselves as individuals whether we use our science wisely. Have we in the clinics sometimes failed to see the patient as a human being and seen him only as a disease or even as a laboratory report? Have we failed to recognize that the vital link between medical science and medical practice is sound medical education? Are we making it clear to the next generation of venereologists that prevention is better than cure and that the mental aspects of venereal disease are at least as important as the physical?

In our excitement over the host we must not forget the parasite. Some of us have a secret admiration for the cunning ways in which microbes have thwarted Man's attempts to destroy them. This may be misplaced emotion but we cannot deny that the microbes causing venereal disease are very successful parasites and that there is no immediate prospect of eliminating them. They may yet surprise us with their ingenuity. The best conundrums have no answer.

My thanks are due to Dr. R. G. Tucker of the Dept. of Biochemistry, University of Oxford, to Dr. R. H. Gorrill of the Dept. of Bacteriology, Guy's Hospital Medical School, and to my wife, Dr. Barbara E. Thomas for their constructive criticism and encouragement. I am grateful to the President and Council of the Royal Faculty of Physicians and Surgeons of Glasgow for permission to publish this essay.

\section{REFERENCES}

For much of the early historical information in this essay, reliance has been placed on several well-known texts on the History of Medicine as it has not always been possible to consult the original sources. For descriptions appearing in the last hundred years it has been possible to refer directly to the original literature. Innumerable articles have been consulted. The references listed below are those which are mentioned in the text.

\section{Texts on the History of Medicine}

Bulloch, W. (1938). "The History of Bacteriology", London.

Comrie, J. D. (1932). "History of Scottish Medicine". London.

Encyclopaedia Britannica, 1956 edition, London.

Garrison, F. H. (1924). "An Introduction to the History of Medicine", 3rd ed. London.

Graham, H. (1939). "Surgeons All". Rich and Cowan, London.

Major, R. H. (1945). "Classic Descriptions of Disease", 3rd ed. Thomas, Springfield, Ill.

(1954). "A History of Medicine". Thomas, Springfield, Ill.

Osler, W. (1921). "The Evolution of Modern Medicine". New Haven.

\section{OTHER REFERENCES}

Anderson, K. (1943), Science, 97, 560.

, Goodpasture, E. W., and DeMonbreun, W. A. (1945). J.exp. Med., 81, 41.

DeMonbreun, W. A., and Goodpasture, E. W. (1945). Ibid., 81, 25.

Arnold, R. C., Wright, R. D., and Levitan, S. (1950). Amer. J. Syph., 34, 324, 327.

,-- and McLeod, C. (1950). Ibid., 34, 327.

Bassi, A. (1835-36). "Del mal del segno calcinaccio o moscardino". Orcesi, Lodi.

Behring, E. (1890). Dtsch. med. Wschr., 16, 1145.

and Kitasato, S. (1890). Ibid., 16, 1113.

Bell, B. (1793). "A Treatise on Gonorrhoea Virulenta and Lues Venerea". Watson and Mudie, Edinburgh.

Benivieni, A. (1505). "De abditis nonnullis ac mirandis morborum et sanationum causis". Florence.

Bettinger, J. (1856). Aerztliches Intelligenz-Blatt, München, 3, 425.

Bigger, J. W. (1943). Lancet, 1, 457.

Blumberg, J. M., Hartney, J. B., and Dimmock, M. O. (1950). Amer. J. clin. Path., $20,367$.

Bordet, J. (1895). Ann. Inst. Pasteur, 9, 462.

(1898). Ibid., 12, 688.

- and Gengou, O. (1901). Ibid., 15, 289.

Boswell, J. (1763). “Boswell's London Journal, 1762 1763 ", ed. F. A. Pottle, 1950. Heinemann, London.

Bretonneau, P. F. (1826). "Des inflammations spéciales du tissu muqueux". Crevot, Paris.

Browning, C. H. (1910). Brit. med.J., 2, 1439.

-, Cruickshank, J., and Mackenzie, I. (1910). J. Path. Bact., 14, 484.

— and Mackenzie, I. (1911). "Recent Methods in the Diagnosis and Treatment of Syphilis". Constable, London.

Bruck, C. (1906). Dtsch. med. Wschr., 32, 1368.

Bumm, E. von (1885). Ibid., 11, 508, 910.

Burnet, F. M. (1953). "Natural History of Infectious Disease", 2nd ed. University Press, Cambridge.

Cain, R. M. (1953). Canad. J. publ. Hlth, 44, 61. 
Carpenter, C. M., Boak, R. A., Mucci, L. A., and Warren, S. L. (1933). J. Lab. clin. Med., 18, 981.

Chacko, C. W. (1953). J. clin. Path., 6, 227.

Chain, E., Florey, H. W., Gardner, A. D., Heatley, N. G., Jennings, M. A., Orr-Ewing, J., and Sanders, A. G. (1940). Lancet, 2, 226.

Charcot, J. M. (1868). Arch. Physiol. norm. path., 1, 161, 379.

- (1869). Ibid., 2, 121.

and Bouchard, A. (1866). Gaz. méd. Paris, 3 sér., 21, 122.

Clowes, W. (1579). "The Cure of the Morbus Gallicus by Unctions." Day, London.

Clutton, H. H. (1886). Lancet, 1, 391.

Cockburn, W. (1719). "The Symptoms, Nature, Cause and Cure of a Gonorrhoea", 3rd ed. Strahan, London.

Colles, A. (1837). "Practical Observations on the Venereal Disease". Sherwood, London.

Corrigan, D. J. (1832). Edinb. med. surg. J., 37, 225,

Credé, K. S. F. (1881a). Arch. Gynäk., 17, 50.

- (1881b). Ibid., 18, 367.

Cumming, H. S., Hazen, H. H., Sanford, A. H., Senear, F. E., Simpson, W. M., and Vonderlehr, R. A. (1935). J. Amer. med. Ass., 104, 2083.

D'Alessandro, G., and Dardanoni, L. (1953). Amer. J. Syph., 37, 137.

Davis, B. D., Moore, D. H., Kabat, E. A., and Harris, A. (1945). J. Immunol., 50, 1.

Detre, L. (1906). Wien. klin. Wschr., 19, 619.

Dickinson, W. H. (1865). Lancet, 1, 568.

Dienes, L. (1940). Proc. Soc. exp. Biol. (N.Y.), 44, 468. and Edsall, G. (1937). Ibid., 36, 740.

Dobell, C. (1932). "Antony van Leeuwenhoek and His Little Animals". London.

Döhle, K. (1895). Disch. Arch. klin. Med., 55, 190.

Domagk, G. (1935). Dtsch. med. Wschr., 61, 250.

Donath, J., and Landsteiner, K. (1904). Münch. med. Wschr., 51, 1590. (1905). Z. klin. Med., 58, 173.

Donné, M. A. (1836). C. R. Acad. Sci. (Paris), 3, 385.

Donovan, C. (1905). Indian med. Gaz., 40, 411.

Dressler (1854). Virchows Arch. path. Anat., 6, 264.

Ducrey, A. (1889). Mh. prakt. Derm., 9, 387.

Durand, J., Nicolas, J., and Favre, M. (1913). Bull. Soc. méd. Hôp. Paris, 35, 274.

Durham, H. E. (1896). Proc. roy. Soc., 59, 224.

Eagle, H., and Fleischman, R. (1948).J. exp. Med., 87, 369. , Gude, A. V., Beckmann, G. E., Mast, G., Sapero, J. J., and Shindledecker, J. B. (1949). J. Amer. med. Ass., 140, 940.

, Magnuson, H. J., and Fleischman, R. (1946). $J$ vener. Dis. Inform., 27, 3.

Eberson, F. (1921). Arch. Derm. Syph. (Chicago), 4, 490.

Ehrlich, P., and Hata, S. (1910). "Die Experimentelle Chemotherapie der Spirillosen, etc." Springer. Berlin.

___ and Shiga, K. (1904). Berl. klin. Wschr., 41, 329, 362.

Emmerich, R., and Löw, O. (1899). Z. Hyg. Infekt.-Kr., 31, 1 .

Esmarch, F., and Jessen, W. (1857). Allg. Z. Psychiat., 14, 20.

Felix, A. (1942). Brit. med.J., 2, 597.

Fleming, A. (1929). Brit. J. exp. Path., 10, 226.

Fourneau, E., Tréfouël, J., Tréfouël, J., Nitti, F., and Bovet, D. (1936). C. R. Soc. Biol. (Paris), 122, 258.

Fournier, A. (1882). "De l'ataxie locomotrice d'origine syphilitique". Masson, Paris.
Fracastorius, H. (1530). "Syphilis sive morbus gallicus". Verona.

(1546). "De contagione, etc.". Venice (trans. W. C. Wright, 1930).

Fraenkel, C., and Sobernheim, J. F. (1894). Hyg. Rdsch. (Berl.), 4, 97, 145.

Frei, W. (1925). Klin. Wschr., 4, 2148.

Freundt, E. A. (1956). Brit. J. vener. Dis., 32, 188.

Gale, E. F. (1953). Advanc. Protein Chem., 8, 285. and Folkes, J. P. (1953a). Biochem. J., 53, 493.

- - (1953b). Ibid., 55, 721 .

Goissedet, P., Despois, R., Gailliot, P., and Mayer, R. (1936). C.R. Soc. Biol. (Paris), 121, 1082.

Gruber, M. von (1896). Münch. med. Wschr., 43, 206.

Grünbaum, A. S. (1897). Ann. Inst. Pasteur., 11, 670.

Gull, W. (1876). Trans. path. Soc. Lond., 27, 413.

Hardy, P. H., and Nell, E. E. (1955). J. exp. Med., 101, 367.

Harley, G. (1865), Lancet, 1, 568.

Hellerström, S., and Wassén, E. (1931). C.R. Soc. Biol. (Paris), 106, 802.

Henle, F. G. J. (1840). “Pathologische Untersuchungen”. Berlin.

Henriksen, S. D. (1947). J. Immunol., 55, 153.

Herxheimer, K. and Krause (1902). Disch. med. Wschr., 28, 895 .

Heyman, A., Sheldon, W. H., and Evans, L. D. (1952). Brit. J. vener. Dis., 28, 50.

Hoffmann, E. (1906). Disch. med. Wschr., 32, 496.

- (1912). Derm. Z., 19, 1043. (1913). Ibid., 20, 220.

Howells, L., and Kerr, J. D. O. (1946). Lancet, 1, 51.

Hudson, E. H. (1958). "Non-Venereal Syphilis". Livingstone, Edinburgh.

Hunter, J. (1786). "A Treatise on the Venereal Disease". London.

Hutchinson, J. (1861). Brit. med. J., 1, 515. (1871). Med.-chir. Trans., 54, 317 (1876). Trans, path. Soc. Lond., 27, 341

Huxley, J. (1957). Sunday Times, London, July 14.

Iwanowsky, D. (1892). Bull. Acad. Sci. St.-Pétersb., 35 (n.s.3), 67.

Jarisch, A. (1895). Wien. med. Wschr., 45, 720.

Kahn, R. L. (1922). Arch. Derm. Syph. (Chicago), 5, 570.

King, A. (1958). Lancet, 1, 651.

Klebs, A. C. (1906). J. Amer. med. Ass., 46, 1716. (1932). Science, 75, 191.

Klebs, E. (1878). Prag. med. Wschr., 3, 409. (1879). Arch. exp. Path. Pharmak., 10, 161.

Koch, R. (1881). Mitth. kaiserl. GesundhAmte, 1, 1.

Kolmer, J. A. (1942a). Arch. Derm. Syph. (Chicago), 45, 455.

(1942b). Amer. J. clin. Path., 12, 480.

(1947). Arch. Derm. Syph. (Chicago), 56, 179.

(1948). Ibid. 57, 965.

(1950). Ibid:, 61, 49.

(1953). Amer. J. Syph., 37, 77.

Kraus, R. (1897). Wien. klin. Wschr., 10, 736.

Lancisi, G. M. (1738). "De motu cordis et aneurysmatibus". Naples.

Landsteiner, K., and Mucha, V. (1906). Wien. klin. Wschr., 19, 1349.

-, Müller, R., and Pötzl, O. (1907). Ibid., 20, 1565.

Lange, K. (1912). Berl. klin. Wschr., 49, 897. (1913). Z. Chemother., 1, 44.

League of Nations (1928). "Report of the 2nd Laboratory Conference on the Sero-diagnosis of Syphilis", Copenhagen, 1928. League of Nations Publications, 1929, iii, 3, Geneva. 
Levaditi, C. (1906). C.R. Soc. Biol. (Paris), 60, 67. and Yamanouchi, T. (1907). Ibid., 63, 740.

Loeffler, F., and Frosch, P. (1898). Disch. med. Wschr., $24,80$.

Louis, P. C. A. (1825). "Recherches anatomico-pathologiques sur la phthisie". Paris.

(1835). "Recherches sur les effets de la saignée dans quelques maladies inflammatoires, etc.". Paris.

McLeod, C. P., and Magnuson, H. J. (1953). Publ. Hlth Rep. (Wash.), 68, 747.

McLeod, J. W. (1947). Brit. J. vener. Dis., 23, 53.

Magnuson, H. J., Eagle, H., and Fleischman, R. (1948). Amer. J. Sypr., 32, 1.

_. Thomas, E. W., Olansky, S., Kaplan, B. I., Mello, L. de, and Cutler, J. C. (1956). Medicine (Baltimore), $35,33$.

— and Thompson, F. A. (1949). J. vener. Dis. Inform., 30, 309.

Marie, A., and Levaditi, C. (1907). Ann. Inst. Pasteur, 21, 138.

Marquardt, M. (1949). "Paul Ehrlich”. London.

Marten, B. (1720). "A New Theory of Consumptions, etc." (2nd ed., 1722).

Medical Research Committee (1918). Spec. Rep. Ser. med. Res. Ctte. Lond., No. 19.

Meinicke, K. von (1956). Hautarzt, 7, 540.

Metchinikoff, E. (1895). Ann. Inst. Pasteur, 9, 433. and Roux, E. (1903). Ibid., 17, 809. (1904a). Ibid., 18, 1. (1904b). Ibid., 18, 657

Michaelis, L. (1907). Berl. klin. Wschr., 44, 1477.

Milgrom, F. (1948). Rev. Immunol., 12, 348.

Miller, J. N., Boak, R. A., and Carpenter, C. M. (1957). J. Amer. med. Ass., 163, 112.

Ministry of Health (1956). Annual Report of the C.M.O. for 1954. Brit. J. vener. Dis., 32, 47.

Moon, H. (1876). Trans. odont. Soc. Lond., n.s. 9, 223.

Moore, J. E., and Mohr, C. F. (1952). J. Amer. med. Ass., 150,467

Morgagni, J. B. (1769). "The Seats and Causes of Diseases Investigated by Anatomy", trans. from Latin by B. Alexander. London.

Müller, R., and Oppenheim, M. (1906). Wien. klin. Wschr., 19, 894.

Murri, A. (1885). Riv. clin. Bologna, 3 ser., 5, $241 ; 321$.

Neisser, A. (1879). Zbl. med. Wiss., 17, 497.

Nelson, R. A. (1952). Brit. J. vener. Dis., 28, 160. (1953). Science, 118, 733. and Diesendruck, J. A. (1951). J. Immunol., 66, 667. and Mayer, M. M. (1949). J. exp. Med., 89, 369.

Nicol, C. S., and Edward, D. G. ff. (1953). Brit. J. vener. Dis., 29, 141 .

Nicolle, C. (1899). C.R. Soc. Biol. (Paris), sér. 11, 1, 778. (1923). Ibid., 88, 871 .

Nissl, F. (1904). "Histologische und histopathologische Arbeiten über die Grosshirnrinde", vol. 1. Fischer, Jena.

Noguchi, H. (1911). J. exp. Med., 14, 99.

and Moore, J. W. (1913). Ibid., 17, 232.

Ogston, A. (1881). Brit. med. J., 1, 369, 453. (1882). J. Anat. (Lond.), 16, 526. (1883). Ibid., 17, 24.

Olansky, S.,.Harris, A., and Price, E. V. (1956). Brit. J. vener. Dis., 32, 104.

Pangborn, M.C.(1941).Proc.Soc.exp. Biol.(N.Y.), 48, 484. (1942). J. biol. Chem., 143, 247. (1945). Ibid., 161, 71 .
Paré, A. (1840-1841). "Oeuvres complètes d'Ambroise Paré", 3 vols, ed. J. F. Malgaigne. Baillière, Paris.

Park, J. T., and Strominger, J. L. (1957). Science, 125, 99.

Parran, T., Hazen, H. H., Mahoney, J. F., Sanford, A. H., Senear, F. E., Simpson, W. M., and Vonderlehr, R. A. (1937). J. Amer. med. Ass., 109, 425.

Pasteur, L., and Joubert, J. F. (1877). C.R. Acad. Sci. (Paris), 85, 101.

Pellizzari, P. (1862). "Della trasmissione della sifilide mediante l'inoculazione del sangre". Florence.

Penrose, C. A. (1898). Bull. Johns Hopk. Hosp., 9, 140.

Petri, R. J. (1887). Zbl. Bakt., 1, 279.

Pfeiffer, R. (1894). Z. Hyg. Infekt.-Kr., 18, 1.

Porges, O., and Meier, G. (1908). Berl. klin. Wschr., 45, 731 .

Portnoy, J., and Magnuson, H. J. (1955). J. Immunol., 75, 348

- (1956). Amer. J. clin. Path., 26, 313.

Price, I. N. Orpwood (1933). "The Complement Fixation Test for Gonorrhoea”. L.C.C., London.

_ and Whelan, M. J. (1957). Brit. J. vener. Dis., 33, 18. and Wilkinson, A. E. (1950). Lancet, 1, 14.

(1952). Brit. J. vener. Dis., 28, 16.

Puccinelli, V. A. (1951). Amer. J. Svph., 35, 340.

Reenstierna, J. (1921). Acta derm.-venereol. (Uppsala), 2, 1.

Ricord, P. (1838). "Traité pratique des maladies vénériennes". Paris.

Robertson, D. Argyll (1869a). Edinb. med. J., 14, 696.

(1869b). Ibid., 15, 487.

Romberg, M. H. (1846). "Lehrbuch der Nerven-Krankheiten des Menschen" (2nd ed., 1851). Duncker, Berlin.

Rosenbach, O. (1880). Berl. klin. Wschr., 17, 132, 151.

Ruge, H., Knothe, H., and Otten, O. (1957). Disch. med. Wschr., 82, 1231.

Salaman, M. H., King, A. J., Williams, D. I., and Nicol, C. S. (1944). Lancet, $2,7$.

Saurino, V. R., and DeLamater, E. D. (1952). Amer. J. Syph., 36, 353.

Schaudinn, F. (1905). Dtsch. med. Wschr., 31, 1665.

and Hoffmann, E. (1905). Arb. k. GesundhAmite, 22, 527.

Sheehan, H. L. (1944). Lancet, 2, 8.

Singer, C. (1911). Janus, 16, 81 .

Sneath, P. H. A. (1957a). J. gen. Microbiol., 17, 184.

(1957b). Ibid., 17, 201.

Stannus, H. S. (1933). "A Sixth Venereal Disease". Baillière, Tindall and Cox, London.

Tate, N. (1686). "Syphilis or a Poetical History of the French Disease" (a translation of Fracastorius' Latin poem). London.

Thomas, H. W. (1905). Brit. med. J., 1, 1140.

Tomasczewski, E. (1903). Z. Hyg. Infekt.-Kr., 42, 327.

Tréfouël, J., Tréfouël, J., Nitti, F., and Bovet, D. (1935). C.R. Soc. Biol. (Paris), 120, 756.

Turner, T. B. (1939). J. exp. Med., 69, 867.

, Kluth, F. C., McLeod, C., and Winsor, C. P. (1948). Amer. J. Hyg., 48, 173.

Vallambert, S. de (1565). "De la manière de nourrir et gouverner les enfans dès leur naissance". Poitiers.

Vieussens, R. de (1715). "Traité nouveau de la structure et des causes du mouvement naturel du coeur". Guillemette, Toulouse.

Virchow, R. (1847). Virchows Arch. path. Anat., 1, 3. (1858a). "Die Cellularpathologie in ihrer Begründung auf physiologische und pathologische Gewebelehre". Berlin. (1858b). Virchows Arch. path. Anat., 15, 217. 
Wagner-Jauregg, J. (1887). Jb. Psychiat. Neurol., 7, Weil, E., and Felix, A. (1916a). Wien. klin. Wschr., $29,33$. 94.

(1918-19). Psychiat.-neurol. Wschr., 20, 132, 251.

Wallace, W. (1836). Lancet, 1835-36, 2, 5.

Warren, S. L., Scott, W. W., and Carpenter, C. M. (1937). J. Amer. med. Ass., 109, 1430.

Wassermann, A., Neisser, A., and Bruck, C. (1906). Disch. med. Wschr., 32, 745.

(1916b). Ibid., 29, 974.

Widal, F. (1896). Bull. Soc. méd. Hôp. Paris, 13, 561.

Wiener, N. (1948). "Cybernetics or Control and Communication in the Animal and the Machine". Wiley, New York.

Wilkinson, A. E. (1954). Brit. J. vener. Dis., 30, 144. (1957). Ibid., 33, 25. Infekt.-Kr., 55, 451 . Rep., 7, 373.

and Plaut, F. (1906). Dtsch. med. Wschr., 32 1769.

$$
\text { Rep., 7, } 373 .
$$

Work, E. (1957). Nature (Lond.), 179, 841.

Zinsser, H. (1934). Amer. J. Hyg., 20, 513. 